\title{
Proposals for improvement of Annex I of Directive 92/43/ EEC: Central Italy
}

Simona Casavecchia ${ }^{1}$, Marina Allegrezza ${ }^{1}$, Claudia Angiolini², Edoardo Biondi ${ }^{1}$, Federica Bonini ${ }^{3}$, Eva del Vico ${ }^{4}$, Emanuele Fanfarillo ${ }^{2}$, Bruno Foggi ${ }^{5}$, Daniela Gigante ${ }^{3}$, Lorenzo Gianguzzi ${ }^{6}$, Cesare Lasen ${ }^{7}$, Simona Maccherini ${ }^{2}$, Mauro Mariotti ${ }^{8}$, Simone Pesaresi ${ }^{1}$, Gianfranco Pirone ${ }^{9}$, Livio Poldini ${ }^{10}$, Federico Selvi ${ }^{11}$, Roberto Venanzoni ${ }^{12}$, Daniele Viciani $^{5}$, Marisa Vidali ${ }^{10}$, Giampiero Ciaschetti ${ }^{13}$

1 Department of Agricultural, Food and Environmental Sciences (D3A), Polytechnic University of Marche, Via Brecce Bianche, I-60131 Ancona, Italy

2 Department of Life Sciences, University of Siena, Via P.A. Mattioli 4, I-53100 Siena, Italy

3 Department of Agricultural, Food and Environmental Sciences (DSA3), University of Perugia, Borgo XX giugno 74, I-06121 Perugia, Italy

4 Department of Environmental Biology, Sapienza University of Rome, Piazzale A. Moro 5 I-00185 Rome, Italy

5 Department of Biology (BIO), University of Florence, Via G. La Pira 4, 50121 Firenze, Italy

6 Department of Agricultural, Food and Forest Sciences University of Palermo, Viale delle Scienze 4, I- 90128 Palermo, Italy

7 Via Mutten 27, I-32032 Arson di Feltre (BL), Italy

8 Department of Earth, Environment and Life Sciences, University of Genova, Corso Europa 26 I-16132 Genova, Italy

9 Department of Life, Health and Environmental Sciences, University of L'Aquila, Piazzale Salvatore Tommasi, I-67100 L'Aquila, Italy

10 Department of Life Sciences, University of Trieste, Via Licio Giorgieri 5, I-34127 Trieste, Italy

11 Department of Agriculture, Food, Environment and Forestry (DAGRI), Laboratories of Environmental and Applied Botany, P.le Cascine 28, I-50144

Florence, Italy

12 Department of Chemistry, Biology and Biotechnologies, University of Perugia, Polo Didattico Via del Giochetto 6, I-06122 Perugia, Italy

13 Plant Biodiversity Monitoring and Conservation Office, Maiella National Park, Via Badia 28, I-67039 Sulmona (AQ), Italy

Corresponding author: Simona Casavecchia s.casavecchia@univpm.it

Subject editor: Simonetta Bagella • Received 17 December 2021 • Accepted 29 December 2021 • Published 31 December 2021

\section{Abstract}

The main purpose of the 92/43/EEC Habitats Directive is to contribute to the conservation of biodiversity, understood as habitat types and species of the flora and fauna of the European Union. To achieve this goal, natural and semi-natural biodiversity as a whole must be recognized and included in its annexes. As for the conservation of biotopes, named habitat types, Italy is unfortunately lacking as it the Annex I does not include important ecosystems that are typical of its territory, rare for biogeographical reasons or threatened. Therefore, the opportunity to identify a first list of significant habitats for central Italy is discussed here. For each of the new proposed types (new habitats or new subtypes) a sheet has been prepared to highlight their salient characteristics. The new proposals concern seven habitat types and one subtype: sedge and reeds formations (Freshwater large sedge and reed beds), willow shrublands (Shrubby willow formations of river banks and fens), Apennine garrigues (Apennine hilly and montane garrigues), a new subtype of Annex I Habitat 6130 (Communities of herbaceous and dwarf shrub-suffrutescent plants of Italian ultramafic substrates), ancient olive groves ("Centuries-old olive groves" with evergreen Quercus spp. and arborescent matorral), secondary meadows (Italian submontane and montane pastured meadows dominated by Cynosurus cristatus), badlands (Pioneer halophilous and sub-halophilous communities of "calanchi" and "biancane" badlands) and hop-hornbeam woods (Italian-Balkan hop-hornbeam woods).

\section{Keywords}

badlands, calaminarian grasslands, freshwater vegetation, garrigues, meadows, neglected habitats, olive groves, shrubby willow formations, ultramafic plant communities, woods 


\section{Introduction}

The 92/43/EEC Habitats Directive (European Union 1992) represents the most important and effective tool that the European Union has for safeguarding the biodiversity of its territory (Evans 2006; Lockwood 2006).

Due to problems related to the incomplete knowledge of the biodiversity heritage at the time of accession to the Directive, and to a probable initial underestimation of the European conservation plan by the Italian State, Annexes I, II, IV, and V are unfortunately far from including the entire heritage of Italian species and habitats worthy of being protected. The same happens for other European countries (Cardoso 2012; van Swaay 2012; Hochkirch et al. 2013; Moreno-Saiz 2021).

The Habitats Directive, as mentioned in Article 19, provides for the possibility of amendments of the Annexes which are considered necessary "for adapting Annexes I, II, III, V and VI to technical and scientific progress". Even if, as some believe, this may not be the right time to request amendments since the priority should be the full implementation of the existing Directive (Maes et al. 2013), we believe it is appropriate to start discussing and hypothesizing some new entries in Annex I, as other countries have already done (Oprea and Sârbu 2009).

While for the Alpine sector the gaps are less serious as the neighboring States have included in Annex I many habitats occurring in the Italian Alps as well, for central Italy and the Apennines in particular the lack of habitats of community interest appears particularly serious, as many endemic and rare vegetation types are not mentioned, and therefore they are devoid of any form of protection. The issue is even more alarming if we consider the crucial ecological role they play also for the conservation of wild fauna and flora. The situation does not appear different if plant communities and ecosystems of a secondary origin are taken into consideration harmoniously integrated into natural contexts. Although resulting from the transformations made by human in the territory over the centuries, these traditional anthropic ecosystems are rich in biodiversity and represent an important element of the human historical and cultural heritage (Saccani 2002; Young et al. 2005; Angold et al. 2006; McNeely et al. 2006; Halada et al. 2011; Torma et al. 2018).

In the light of this awareness, and thanks to the enormous contribution of naturalists in the application of the Directive itself, a significantly deeper level of knowledge has been reached in the last 3 decades, and the scientific community is now better able to reach an exhaustive synthesis on the heritage of species, habitats, or more generally ecosystems of conservation interest. Therefore, proposals have been formulated for the inclusion of new habitats for Italy, pending the granting of the possibility of integrating Annex I by the European Commission, as required by Art. 19 of the Directive itself. At the moment of the preparation of the Italian Interpretation manual of Habitats Directive (Biondi et al. 2009, 2012) a first list of neglected habitats for Italy was compiled and sent to the
Italian Ministry of Environment, soliciting their inclusion in Annex I. In the following years, this first habitat list has been updated and expanded. The most important habitats proposed for inclusion in Annex I for central Italy are here presented, paying a particular attention to the Apenninic habitat types.

Similarly, in other articles in this volume, new habitats or new subtypes are proposed for Sicily and Sardinia (Guarino et al. 2021; Fois et al. 2021) and more will probably be identified for the entire Italian territory and even other countries.

\section{Materials and Methods}

The habitats are presented following a standard shared format designed to briefly illustrate their salient qualitative characteristics, deferring to future dedicated monographs a more detailed and complete analysis of each habitat, providing exhaustive descriptions of geographic variants and subtypes (when present) and phytosociological tables as well.

The new proposed habitats can fall into one of the following cases:

i) New subtype or new variant of a habitat already occurring in the Annex I, in order to include aspects not foreseen in the general description of the habitat for Italy;

ii) description of a new habitat not yet present in the Annex I: in this case the macrocategory and the related subcategory are indicated;

iii) reporting of a habitat already included in the Annex I but not yet recognized for Italy.

In the habitat sheet, the following information is provided:

Name of the habitat type/subtype/variant;

Macrotype: macrocategory and subcategories;

Type of the proposal: new habitat, new subtype/variant, first recognition for Italy of a habitat of the Annex I, and name/s of the proposer/s;

Reason for the proposal: scientific justification on the need for the inclusion of the new habitat into Annex I;

Diagnostic sentence: synthetic phrase that indicates the salient characteristics of the habitat;

Syntaxonomic reference: framed to the level of alliance(s), followed by the higher ranks $[\operatorname{order}(s)$ and class(es)] referring to the Italian Vegetation Prodrome (Biondi and Blasi 2015);

Reference list of diagnostic species: a list of species (generally not more than 10) which better characterise the habitat. The species marked with an asterisk are listed in Annex II. In many cases, the list of diagnostic species should be supplemented with "regional" or endemic species, at this stage not included due to the synthetic scope of the present contribution. The plant species nomenclature and taxonomy follow Bartolucci et al (2018) and the updates of The Portal to the Flora of Italy (available at http:/dryades.units.it/floritaly accesed November 2021) 
Dynamic relationships and contacts: successional context of the habitat and spatial relations with other vegetation types.

\section{Results}

The sheets of the habitats whose role is considered relevant for the biodiversity of central Italy are presented below, ordered according to the numbering of the reference:

[15xx] "Pioneer halophilous and sub-halophilous communities of "calanchi" and "biancane" Badlands";

[31xx] "Freshwater large sedge and reed beds";

[32xx] "Shrubby willow formations of river banks and fens";

[40xx] "Apennine hilly and montane garrigues";

[6130] "Calaminarian grasslands of the Violetalia calaminariae" subtype "Communities of herbaceous and dwarf shrub-suffrutescent plants of Italian ultramafic substrates";

[63xx] "Centuries-old olive groves" with evergreen Quercus spp. and arborescent matorral";

[65xx] "Italian submontane and montane pastured meadows dominated by Cynosurus cristatus";

[91xx] "Italian-Balkan hop-hornbeam woods".

\section{[15XX] Pioneer halophilous and sub- halophilous communities of "Calanchi" and "Biancane" badlands}

Macrotype: 1 "Coastal and halophytic habitats"; 15 "Salt and gypsum inland steppes" (also 8 "Rocky habitats"; 83 "Other rocky habitats" could be considered if the geomorphological aspect is prevalent).

Type of proposal: New Habitat Proposed (C. Angiolini, F. Fanfarillo, L. Gianguzzi, S. Maccherini, S. Pesaresi, D. Viciani)

Reason for the proposal: The plant communities here proposed as deserving conservation efforts represent a very peculiar habitat type, hosting a number of native, specialized, stress-tolerant species, developing in clayey badlands (calanchi and biancane) along the Apennine chain (Zangheri 1942; Antoni 1965; Ferrari 1971; Ferrari and Grandi 1974; Ferrari and Speranza 1975; Gentile and Sartori 1975; Branconi et al. 1980; Zanotti et al. 1980; Pirone 1981a, 1995; Biondi et al. 1988, 1990, 1992; Ferrari and Gerdol 1987; Brullo et al. 1990; Loppi and De Dominicis 1990; Corbetta et al. 1991; Allegrezza et al. 1993; Chiarucci et al. 1995a, 1995b; Maccherini et al. 1998; Taffettani 2000; Biondi and Pesaresi 2004; Tomei et al. 2009) and in Sicily (Brullo 1985a, 1985b; Brullo and Siracusa 1998; Brullo et al. 1980, 1990, 1998, 2001; Gentile and Di Benedetto 1961; Gianguzzi et al. 2008, 2016a; Musarella et al. 2018; Pasta 2001). These sites host pioneer vegetation types dominated by chamaephytes, hemicryptophytes and therophytes, the latter being adapted to the impenetrable soil crust that develops during the summer.
This vegetation type is rich in rare and endemic species, mainly halophilous and sub-halophilous. When not disturbed, the phytocoenoses of this habitat tend to be permanent, being linked to specific edaphic and micro-environmental conditions. The risk of disappearace of this habitat has two drivers: soil reclamation for agricultural purposes and the decreasing/stopping grazing pressure, which cause a decline of eroded spots. The decrease in total erosion over the whole badlands leads to the expansion of ruderal vegetation types, e.g., Avena fatua dominated grasslands (Torri et al. 2013), at the expense of pioneer halophilous communities.

Diagnostic sentence: Pioneer vegetation of badlands (calanchi and biancane) originated from Plio-Pleistocene marine clays along the Apennine chain of the Italian Peninsula and in Sicily. The different ecological conditions within the badlands originate micro-geosygmeta hosting highly specialized plant communities, rich in halophilous and/or sub-halophilous species.

\section{Subtypes}

Subtype A. Badlands of central and northern Italy with: pioneer perennial vegetation of the alliance Podospermo laciniati-Elytrigion athericae Pirone 1995; annual halophilous and/or sub-halophilous vegetation of the class Saginetea maritimae Westhoff, Van Leeuwen \& Adriani 1962, growing on small, flat areas and micro-terraces of calanchi slopes.

Subtype B. Badlands Calanchi of southern Italy with: pioneer perennial vegetation of the classes Lygeo-Stipetea Rivas-Martínez 1978 and/or Pegano harmalae-Salsoletea vermiculatae Br.-Bl. \& O. Bolòs 1958; annual halophilous and/or sub-halophilous communities in valley floors of calanchi (class Saginetea maritimae Westhoff, Van Leeuwen \& Adriani 1962).

Syntaxonomic reference: Subtype A: perennial communities can be mainly attributed to the alliance Podospermo laciniati-Elytrigion athericae Pirone 1995 (Podospermo laciniati-Elytrigetalia athericae Biondi, Allegrezza \& Pesaresi in Biondi et al. 2014, Artemisietea vulgaris Lohmeyer, Preising \& Tüxen ex Von Rochow 1951), while therophytic communities to the alliance Frankenion pulverulentae Rivas-Martínez ex Castroviejo \& Porta 1976 (Frankenietalia pulverulentae Rivas-Martínez ex Castroviejo \& Porta 1976, Saginetea maritimae Westhoff, Van Leeuwen \& Adriani 1962). Subtype B: perennial communities can be mainly attributed 1) to the alliances Polygonion tenoreani Brullo, De Marco \& Signorello 1990 and Moricandio-Lygeion sparti Brullo, De Marco \& Signorello 1990 (both of Lygeo sparti-Stipetalia tenacissimae Br.-Bl. \& O. Bolòs 1958, Lygeo sparti-Stipetea tenacissimae Rivas-Martínez 1978 ) and 2) to the alliances Salsolo oppositifoliae-Suaedion fruticosae Rigual 1972 and Artemision arborescentis Géhu \& Biondi in Géhu et al. 1986 (Salsolo vermiculatae-Peganetalia harmalae Br.-Bl. \& O. Bolòs 1954, Pegano harmalae-Salsoletea vermiculatae Br.-Bl. \& O. Bolòs 1958), while therophytic communities to the alliances Gaudinio fragilis-Podospermion cani Brullo \& Siracusa 2000 and Frankenion pulverulentae Rivas-Martínez ex 
Castroviejo \& Porta 1976 (Frankenietalia pulverulentae Rivas-Martínez ex Castroviejo \& Porta 1976, Saginetea maritimae Westhoff, Van Leeuwen \& Adriani 1962).

Reference list of diagnostic species: Subtype A, perennial species: Artemisia caerulescens subsp. caerulescens and subsp. cretacea, Thinopyrum acutum, Plantago maritima, Scorzonera cana, Scorzonera laciniata; therophytes: Parapholis incurva, . strigosa, $P$. pycnantha P. cylindrica, Hordeum marinum, $H$. geniculatum. Subtype $B$, perennial species: Lygeum spartum, Limonium calcarae, Limonium optimae, Limonium opulentum, Malva agrigentina, Allium agrigentinum, Herniaria fontanesii subsp. empedocleana, Tripolium sorrentinoi (= Aster sorrentinii), Suaeda kocheri, Reaumuria vermiculata, Scorzonera cana, Cardopatium corymbosum, Atriplex halimus, Salsola oppositifolia, Caroxylon vermiculatum, Capparis sicula, Lotus creticus, Polygonum tenorei; therophytes: Parapholis incurva, $P$. strigosa, P. pycnantha P. cylindrica, Sphenopus divaricatus, Scabiosa parviflora, Anthemis muricata, Hordeum marinum, Aizoanthemopsis hispanicum, Moricandia arvensis.

Dynamic relationships and contacts: Both in central and southern Italy, in transition areas with tension cracks and landsliding of calanchi, the habitat is in catenal contact with annual communities of the class Tuberarietea guttatae (Br.-Bl. in Br.-Bl., Roussine \& Nègre 1952) Rivas Goday \& Rivas-Martínez 1963 nom. mut. propos. Rivas-Martínez, Diaz, Fernández-González, Izco, Loidi, Lousa \& Penas 2002, which are examples of the Habitat $6220^{*}$ "Pseudo-steppe with grasses and annuals of the Thero-Brachypodietea".

In more stable areas, such as the original slopes of calanchi, there are catenal conctats with: Bromoides erecta grasslands of the order Brometalia erecti Br.-Bl. 1936 (Habitat $6210\left(^{*}\right)$ "Semi-natural dry grasslands and scrubland facies on calcareous substrates (Festuco-Brometalia) ( ${ }^{*}$ important orchid sites)" in central and northern Italy; xerophilous grasslands of the order Hyparrhenietalia hirtae Rivas-Martínez 1978 in southern Italy.

In central and northern Italy, in deposition areas with impluvium lines located at the bottom of valleys, there may be contacts with mesophilous grasslands dominated by Arundo plinii or Lolium arundinaceum, as well as with hygro-subalophilous shrublands with Tamarix spp. and riparian woods classified in the alliances Salicion albae Soó 1930 and Populion albae Br.-Bl. ex Tchou 1948, (Habitat 92A0 "Salix alba and Populus alba galleries"). Futher contacts are those with shrub communities of the class Rhamno-Prunetea spinosae Rivas Goday \& Borja ex Tüxen 1962, developing in sites where the erosion stopped.

In the badlands of southern Italy, the coenoses of this habitat have catenal relationships with vegetation types belonging to the series of deciduous forests of the Oleo-Querceto virgilianae sigmetum. In the driest areas of Sicily, there are occasional links with shrublands of the alliance Oleo-Ceratonion (chalky outcrops) or with halo-nitrophilous vegetation types (Miocene clays) of the class Pegano-Salsoletea, and in particular with communities dominated by Salsola oppositifolia and/or Suaeda fruticosa (Brullo et al. 1985). These are generally deforested areas, largely dominated by arable land and extensive crops (Raimondo et al. 2000; Gianguzzi et al. 2014a, 2014b, 2016b).

\section{[31XX] Freshwater large sedge and reed} beds

Macrotype: 3 "Freshwater habitats"; 31 "Standing water"

Type of proposal: New Habitat Proposed (G. Ciaschetti, G. Pirone, R. Venanzoni)

Reason for the proposal: Humid and wet environments are quite rarefied nowadays in Italy like in other countries of Mediterranean basin, mainly because of their continuous reclaim and alteration (Dudgeon et al. 2005). They are very sensitive to eutrophication and pollution by the phytosanitary products used in the agricultural practices and, when deteriorated, they can be subject to invasion by allochthonous species with serious threats to biodiversity conservation (Sartori and Bracco 1997; Malmqvist and Rundle 2002; Pỳsek and al. 2012; Lazzaro et al. 2020). As a consequence, many plant and animal species have become very rare at regional, national or european scale by now (Corbetta and Pirone 1989; Pedrotti 1990, 1995; Venanzoni and Gigante 2000; Pirone et al. 2003; Venanzoni et al. 2003; Bacchetta and Mossa 2004; Prosser and Sarzo 2004; Presti et al. 2005; Ceschin and Salerno 2008; Tomaselli et al. 2006; Tasinazzo 2009; Mereu et al. 2012; Lastrucci et al. 2012, 2014; Gianguzzi et al. 2013; Angiolini et al. 2017; Venanzoni et al. 2021). Some of these phytocoenoses, as tall sedge communities, reach their maximum level of diversity in the mountain karst plains where they represent a relict vegetation with noteworthy phytogeographic disjunctions (Pirone 1987; Biondi and Baldoni 1994; Pedrotti 2015, 2016; Landucci et al. 2013, 2020; Venanzoni et al. 2018; Tardella and Di Agostino 2020; Ciaschetti et al. 2021). In recent years, a sharp decline in helophytic vegetation is clearly observed as testified by many papers on the "Reed die-back syndrome" (Gigante et al. 2011, 2014; Lastrucci et al. 2016, 2017, 2019).

Diagnostic sentence: Marsh and swamp, mono-or paucispecific, azonal vegetation of large sedges (CORINE Biotopes: 53.2) and/or graminoid helophytes (CORINE Biotopes: 53.1), in Temperate and Mediterranean bioclimates, on partially or totally flooded mineral and organic soils, of lakes, rivers shores, humid depressions and peat bogs, with stagnant or weakly flowing freshwater. The aspects dominated by rare large sedges are considered as prioritary. Alophilous and sub-alophilous aspects are not included

Syntaxonomic reference: Magnocaricion elatae Koch 1926, Caricion gracilis Neuhäusl 1959, and Carici pseudocyperi-Rumicion hydrolapathi Passarge 1964 (Magnocaricetalia elatae Pignatti 1953); Phragmition communis Koch 1926 (Phragmitetalia australis Koch 1926). Both the orders are in the Phragmito australis-Magnocaricetea 
elatae Klika in Klika \& Novák 1941 class. The Sardinian association Hyperico hircini-Caricetum microcarpae Bacchetta \& Mossa 2004 needs further studies (Landucci et al. 2020).

Reference list of diagnostic species: Carex elata subsp. elata, C. acuta, C. vesicaria, C. vulpina, C buxbaumii, ${ }^{\star} C$. panormitana, Phragmites australis, Schoenoplectus spp., Butomus umbellatus, Limniris pseudacorus, Typha spp.

Dynamic relationships and contacts: the habitat can be found as substitution stage within hygrophilous series leading to woody formations of Salix alba, S. cinerea, Populus nigra, P. alba, P. canescens (Habitat 92A0), Fraxinus angustifolia (Habitat 91F0), Alnus glutinosa or Ulmus minor (Habitat 91E0*). Some phytocoenoses in sites with prolonged submersion and relatively deep waters $(2-3 \mathrm{~m})$, or linked to the floating aspects, can represent examples of stable vegetation (permaseries).

Topographic contacts are possible with: submerged Chara vegetation (Habitat 3140) or hydrophitic communities of the Lemnetea and Potametea classes (Habitat 3150) in eu-trophic and meso-trophic lakes; vegetation of the Bidention tripartiti alliance (Habitat 3270) along the river banks with accumulation of plant residues; flooded grasslands (Habitat 3280, 3290, 6510) or humid meadows of the Molinion coeruleae alliance (Habitat 6410) in dryer places; peat bogs both high and low, both acidic and calcareous [Habitats $7110^{*}, 7120,7130\left(^{*}\right), 7140,7150$, $7210^{\star}, 7230$ and $7240^{\star}$ Habitats]; rush vegetation of the Agrostio-Scirpoidion holoschoeni (= Molinio-Holoschoenion p.p.) alliance (Habitat 6420); woody communities of the Hyperico hircini-Alnenion glutinosae Dierschke 1975 (Habitat 91E0*) and Rubo ulmifolii-Nerion oleandri O. Bolòs 1985 (Habitat 92D0) syntaxa.

\section{[32XX] Shrubby willow formations of river banks and fens}

Macrotype: 3 "Freshwater habitats"; 32 "Running water" Type of proposal: New Habitat Proposed (E. Biondi, L. Zivkovic)

Reason for the proposal: Riparian vegetation is among those most threatened and at risk of disappearing due to the reckless management of rivers. (Chapin III et al. 2000; Vörösmarty et al 2010; Stubbington et al. 2021). Especially in the middle and terminal stretches, the rivers have been profoundly remodeled also through interventions that have modified their natural course causing the change of river dynamics (Hooke 2006; Camporeale et al. 2013). Furthermore, the excavations of stone materials in the riverbed have profoundly changed the morphology of the river bed and of the banks, causing the disappearance of some communities typical of the banks (Kalníková et al. 2021). Another cause of threat is represented by the invasion of alien species such as Reynoutria japonica, Buddleja davidii, Amorpha fruticosa, Acer negundo and various herbaceous species that are highly competitive with the native willow shrub species (Kumschick et al. 2015; Van Oorschot et al. 2017).

The shrub formations of willows are therefore seriously threatened and in the process of rarefaction; therefore, it is necessary to foresee their conservation considering their important ecological role in maintaining the correct fluvial dynamics and as a place of refuge for wildlife, especially avifauna and endemic plant species (Brullo and Spampinato 1993; Brullo et al. 2000).

Given the absence in Annex I of a habitat in which to include the shrubby willows of the Mediterranean and Continental Macroregions, there is a need to establish a new habitat. Indeed, Habitat 3240 "Alpine rivers and their ligneous vegetation with Salix eleagnos" refers to a very different type of habitat that is located in the mountain stretches of the watercourse and characterized by species such as Salix eleagnos, Salix purpurea subsp. gracilis, Salix daphnoides, Salix nigricans and Hippophae rhamnoides with mainly alpine and perialpine distribution, absent or extremely rare in the Apennines and in central and southern Italy.

Diagnostic sentence: Pioneer formations of shrubby willows that colonize the river banks and the marshy areas of the alluvial plains. Other woody essences (especially Populus alba, P. nigra and Salix alba) are sporadically associated with shrubby willows and assume a clearly subordinate role. They are frequent both in the temperate macrobioclimate (in the sub-Mediterranean variant) mesotemperate bioclimatic belt and in the Mediterranean macrobioclimate, mainly in the mesomediterranean and supramediterranean bioclimatic belts.

Syntaxonomic reference: Salicion apennino-purpureae Allegrezza \& Biondi in Biondi et al. 2014, Salicion triandrae Müller \& Görs 1958, Salicion albae Soó 1930, Salicion incanae Aichinger 1933, Salicetalia purpureae Moor 1958, Salicetea purpureae Moor 1958;

Populion albae Br.-Bl. ex Tchou 1948, Osmundo regalis-Alnion glutinosae (Br.-Bl., P. Silva \& Rozeira 1956) Dierschke \& Rivas-Martínez in Rivas-Martínez 1975, Populetalia albae Br.-Bl. ex Tchou 1948, Salici purpureae-Populetea nigrae Rivas-Martínez \& Cantó ex Rivas-Martínez, Báscones, T.E. Díaz, Fernández-González \& Loidi 2001; Salicion cinereae Müller \& Görs 1958, Salicetalia auritae Doing ex Westhoff in Westhoff \& Den Held 1969, Alnetea glutinosae Br.-Bl. \& Tüxen ex Westhoff, Dijk \& Passchier 1946.

Reference list of diagnostic species: Salix purpurea (subsp. purpurea, subsp. lambertiana and subsp. eburnea), S. triandra subsp. triandra, S. apennina, S. brutia, S. amplexicaulis, S.pedicellata, S. ionica, S. cinerea.

Dynamic relationships and contacts: Pioneer formations of shrubby willows represent the potential vegetation of river beds subject to periodic flooding that prevent the establishment of a more mature hygrophilous forest (Pirone 1981b, 1991, 2000; Corbetta and Pirone 1989; Brullo and Spampinato 1990, 1997; Caniglia et al. 1992; Biondi et al. 1994,1995, 1997, 1999, 2007; Sartori and Bracco 1995; Marchiori and Sburlino 1996; Foggi et al. 2000; Brullo et 
al. 2001; Merloni and Piccoli 2001; Landi et al. 2002; Arrigoni and Papini 2003, Strumia 2004; Angiolini et al. 2005; Gianguzzi and D'Amico 2006; Fascetti and Lapenna 2007) therefore they represent a primitive but long lasting stage, being conditioned by the recurrence of flood events (Pedrotti and Gafta 1996). Their occurrence is of fundamental importance for the stabilization of gravel accumulations which then favor the development of the connected terraces that host more mature hygrophilous woods.

The dynamic relationships with the previous herbaceous stages and with eventual evolutions towards woods are determined above all by the characteristics of hydrological regimes and topography. In general, there are serial connections with the vegetation of the perennial shores (Habitat 3250 "Mediterranean rivers with permanent flow with Glaucium flavum") and annual (Habitat 3270 "Rivers with muddy banks with vegetation of Chenopodion rubri p.p. and Bidention p.p."). The catenal connections occur with the riparian forests of Habitats 92A0 "Salix alba and Populus alba galleries" and 91E0* "Alluvial forests with Alnus glutinosa and Fraxinus excelsior (Alno-Padion, Alnion incanae, Salicion albae)" and with the herbaceous vegetation of the banks of the watercourses of the Habitats 3280 ("Constantly flowing Mediterranean rivers with Paspalo-Agrostidion species and hanging curtains of $\mathrm{Sa}$ lix and Populus alba") and 3290 ("Intermittently flowing Mediterranean rivers of the Paspalo-Agrostidion").

\section{[40xx] Apennine hilly and montane garrigues}

Macrotype: 4 "Temperate heath and scrub"

Type of proposal: New Habitat Proposed (M. Allegrezza, C. Angiolini, G. Ciaschetti, D. Gigante, G. Pirone).

Reason for the proposal: The plant communities here proposed as deserving conservation efforts represent a very peculiar habitat type, hosting a number of stress-tolerant plant species, developed both in primarily inhospitable environments and in naturally degraded biotopes (Chiarucci et al. 1995; Allegrezza et al. 1997; Scoppola and Angiolini 1997; Pirone and Tammaro 1997; Bonini et al. 1999; Biondi 2000; Biondi et al. 2006; Cutini et al. 2007; Pirone et al. 2014, 2018; Ciaschetti et al. 2016, 2018). These communities are mainly composed of chamaephytes and nano-phanerophytes, and embody the typical vegetation of a narrow although ecologically well defined combination of bioclimatic and edaphic conditions occurring all along the Mediterranean basin, mostly at the interface between the Temperate and the Mediterranean Macrobioclimates. They host species from the two main climatic contexts, giving rise to peculiar and exclusive species combination, often including several narrowly distributed taxa. Some orchids genera (e.g., Ophrys and Serapias) are well represented. The already existing habitats belonging to the Macrotype "4" (e.g., 4030, 4060, 4090) do not seem appropriate to host these plant communities, due to their ecological, physiognomic, biogeographic, and bioclimatic characteristics clearly defined in their names and descriptions (Biondi et al. 2009; European Commission 2013).

Diagnostic sentence: Apenninic garrigues and dwarf-garrigues of the inland areas of the Italian peninsula, with rare occurrences also at the foot of the western Alps, characteristic of the areas mostly interested by the Submediterranean Variant of the Temperate Bioclimate, both calcicolous and silicicolous, developed on limestone, sandstone, marl, conglomerate, debris, generally subject to severe erosion. The tipically Mediterranean garigues are not included here, since they can be referred to other, already existing, Annex I Habitat types (e.g., those of the group 54 'Phrygana').

Syntaxonomic reference: Artemisio albae-Saturejion montanae Allegrezza, Biondi, Formica \& Ballelli 1997 and Cerastio tomentosi-Globularion meridionalis Ciaschetti Pirone, Giancola, Frattaroli \& Stanisci 2016 [Artemisio albae-Saturejetalia montanae (Allegrezza, Biondi, Formica \& Ballelli 1997) Biondi \& Allegrezza in Biondi, Allegrezza, Casavecchia, Galdenzi, Gasparri, Pesaresi, Vagge \& Blasi 2014]; Cytiso spinescentis-Saturejion montanae Pirone \& Tammaro 1997 [Cisto cretici-Ericetalia manipuliflorae Horvatic 1958]; Astragalion monspessulani (Biondi, Allegrezza \& Zuccarello 2005) Pirone, Frattaroli \& Ciaschetti 2018 [Astragaletalia monspessulani Pirone, Frattaroli \& Ciaschetti 2018]; Cisto cretici-Micromerietea julianae Oberdorfer ex Horvatić 1958.

Reference list of diagnostic species: Satureja montana subsp. montana, Euphorbia spinosa subsp. spinosa, Helichrysum italicum subsp. italicum, Salvia officinalis subsp. officinalis, Cistus creticus s.l., C. salviifolius, Astragalus monspessulanum subsp. monspessulanus, Helianthemum apenninum subsp. apenninum, $H$. oelandicum s.l., Cephalaria leucantha, Globularia meridionalis, Anthyllis montana s.l., Ziziphora granatensis s.l., Lomelosia crenata s.l.

Dynamic relationships and contacts: These garrigues and dwarf-garigues develop on eroded soils, often with patches of outcropping bedrock, both in primary (e.g., steep rocky slopes, rocky ridges, gullies, and eroded ravines) and secondary sites (regressive aspects as a consequence of fire, overgrazing, etc.), on various substrates, from limestone and travertines to marl-marly limestone to siliceous sandstone, occasionally also on loose substrate. Due to their thermophilic ecology, considering the temperate macroclimatic context, they tend to settle preferentially on hot South-facing slopes, or in sunny and arid locations (Biondi 2000; Allegrezza 2003). From a syndynamic point of view, they often represent either successional stages tending towards evergreen forests (Habitat 9340 "Forests of Quercus ilex and Quercus rotundifolia"), or edapho-xerophilic aspects developed inside a successional process having the mixed deciduous/ evergreen thermophilic forests (Habitat 91AA* "Eastern oak woods"), or the dwarf junipers (Habitat 4060 "Alpine and Boreal heaths", Allegrezza et al. 2013; Ciaschetti et al. 2016) as mature stages. This vegetation can frequently come into contact with the "Semi-natural dry grasslands and scrubland facies on calcareous substrates (Festu- 
co-Brometalia) (*important orchid sites)" [Habitat 6210 $\left.{ }^{*}\right)$ ], with the "Pseudo-steppe with grasses and annuals of the Thero-Brachypodietea" (Habitat 6220*), with the "Rupicolous calcareous or basophilic grasslands of the Alysso-Sedion albi" (Habitat 6110*), with the "Juniperus communis formations on heaths or calcareous grasslands" (Habitat 5130), with the "Arborescent matorrals of Juniperus spp." (Habitat 5210), and less frequently with the "European dry heaths" (Habitat 4030), giving rise to articulated vegetational mosaics.

\section{[6130] Calaminarian grasslands of the Violetalia calaminariae}

Macrotype: 6 "Natural and semi-natural grassland formations" 61 "Natural grasslands"

Type of proposal: new subtype proposed "Communities of herbaceous and dwarf shrub-suffrutescent plants of Italian ultramafic substrates" (M. Mariotti, B. Foggi, F. Selvi, D. Viciani)

Reason for the proposal: The communities of herbaceous and dwarf shrub-suffrutescent plants typical of Italian ultramafic soils have been generally referred to Habitat 6130 based on broad ecological similarity, rather than on syntaxonomical evidence. In fact, the floristic differences with Violetalia calaminariae vegetation are remarkable (Ernst 1974, 1976). In the Italian interpretation manual, the peculiarities of the Italian vegetation types have been specified with reference mainly to the Ligurian communities. We believe that the habitats strictly associated with the Italian ultramafic soils should deserve a separate treatment in the Annex I of Directive 92/43. Since at this stage this is not feasible, however, the alternative proposed here is to adopt a more inclusive concept and diagnostic phrase for Habitat 6130, as to include several Italian variants of the ultramafic outcrops in the Alps, northern Apennines, Elba, and the old mining dumps of Sardinia and other areas.

The vegetation of the ultramafic soils, rich in endemic taxa, is widespread mainly in Liguria and Toscana, but there are also examples on the outcrops of Emilia-Romagna, Lombardia, Piemonte and Val d'Aosta (Pignatti-Wikus and Pignatti 1977; Arrigoni et al. 1983; Nowak 1987; Chiarucci 1994, 2004; Mariotti 1994, 2008; Chiarucci et al. 1995, 1996, 1998a, 1998b, 1998c, 1999; Vagge 1997; Buffa et al. 1998; Saccani 1998, 2002; Adorni and Tomasselli 2002; Chiarucci and Mariotti 1999; Viciani et al. 2002, 2005; Foggi et al. 2006; Selvi 2007; Foggi and Venturi 2009; Marsili and Barberis 2012; D’Amico and Previtelli 2012; D’Amico et al. 2013; Saccani and Salvati 2015; Tomaselli et al. 2019a, 2019b, 2021). The plant communities on these outcrops usually form a fine mosaic due to slight geomorphological variations that support patches of different physiognomic types, such as suffrutescent, succulent herbaceous and/or therophytic communities of oligotrophic substrates and formations of graminoid herbs; there are also chasmophytic and scree communi- ties where the substrate, stable or mobile, becomes more selective. In past studies, this mosaic was analysed as a whole using large relevés surfaces, thus leading to contrasting phytosociological classifications. The assignment of these Italian plant communities to the order Violetalia calaminariae, hence to Habitat 6130, appears inadequate from a syntaxonomical point of view. In fact, some important diagnostic species of this habitat mentioned in the European Manual (European Commission 2013) - such as Viola calaminaria (now V. lutea subsp. calaminaria), Festuca ophioliticola, Cochlearia alpina (now C. pyrenai$\mathrm{ca}$ ), are not found on the Italian outcrops. For this reason, the distinctness of the vegetation of the serpentine soils in northwest and central Italy would justify an ad-hoc habitat type characterized by many endemic and/or rare species, among which Nickel hyperaccumulator taxa. At this stage, however, we propose to broaden the concept of Habitat 6130 as to include different variants often in close spatial contact within the same highly specialized geolithological context. The semi-natural formations found in abandoned or not abandoned mining sites (mines of Sulcis-Iglesiente in south-western Sardegna, of Campiglia Marittima in western Toscana, of Valganna and Valvassera in the Lombardia Alps, of Cogne in Val d'Aosta, of Raibl in Carnia, etc., see e.g. Carnelli et al. 1994; Mariotti and Carnelli 1995; Angiolini et al. 2005) can also be included in this type of habitat.

Diagnostic sentence: herbaceous or herbaceous-suffrutescent formations with sparse cover (30-50\%), natural or semi-natural, on shallow soils often with rocky or gravelly outcrops, rich in heavy metals (e.g., nickel, zinc, chromium, copper), mostly of ultramafic nature, locally in mining districts. The flora is highly specialized, with taxa adapted to heavy metals and often Ni-hyperaccumulators of family Brassicaceae. Variants are recognized based on geographical distribution, floristic composition and nature of the substrate.

Syntaxonomic references: the large heterogeneity of the floristic-ecological types found on ultramafic substrates is reflected in the syntaxonomic attributions below.

Alyssion bertolonii Pignatti in E. Pignatti \& Pignatti 1977, Rosmarinetalia officinalis Br.-Bl. ex Molinier 1934, Rosmarinetea officinalis Rivas-Martínez, T.E. Diáz, F.Prieto, Loidi \& Penas 2002 (first and part of the third variant, see discussion); Ptilostemo casabonae-Euphorbion cupanii Angiolini, Bacchetta, Brullo, Casti, Giusso Del Galdo et Guarino 2005, Scrophulario-Helichrysetalia italici Brullo 1984, Thlaspietea rotundifolii Br.-Bl. 1948 (second variant); Cistion ladaniferi Br.-Bl. In Br.-Bl., Molinier \& Wagner 1940, Lavanduletalia stoechadis Br.-Bl. In Br.Bl., Molinier \& Wagner 1940 em. Rivas-Martínez 1968, Cisto ladaniferi-Lavanduletea stoechadis Br.-Bl. In Br.Bl., Molinier \& Wagner 1940 (part of the third variant); Bromion erecti Koch 1926, Brometalia erecti Koch 1926, Festuco valesiacae-Brometea erecti Br.-Bl. et Tx. ex Br.-Bl. 1949 (fourth variant); Oxytropido-Kobresion myosuroidis Br.-Bl. (1948) 1949 nom. mut. propos. Rivas-Martínez, Diaz, Fernández-González, Izco, Loidi, Lousa \& Penas 
2002, Oxytropido-Kobresietalia myosuroidis Oberdorfer 1957 nom. mut. propos. Rivas-Martínez, Diaz, Fernández-González, Izco, Loidi, Lousa \& Penas 2002, Carici rupestris-Kobresietea bellardii Ohba 1974 (fifth variant).

Reference list of diagnostic species: Alyssoides utriculata, Armeria arenaria subsp. apennina, A. denticulata, Cherleria laricifolia subsp. ophiolitica, Euphorbia spinosa, F. robustifolia, Sesleria pichiana, Biscutella pichiana subsp. pichiana and subsp. ilvensis, B. prinzerae, Carex fimbriata, Viola tricolor var. raiblensis, Limonium merxmulleri, Linum muelleri.

Dynamic relationships and contacts: Strong insolation and high selectivity of the substrate determine slow rock weathering and pedogenetic processes, resulting in durable vegetation stages of pioneer type usually connected by spatial contacts. Vegetation dynamics is very slow. In Mediterranean-climate areas the trend is, in principle, towards thermophilous (Cyclamino repandi-Quercetum ilicis) or mesophilous (Cyclamino hederifolii-Quercetum ilicis) holm oak forest types, while in cooler climates, the dynamics is towards semi-deciduous or deciduous oak forests, dominated by Quercus pubescens, Q. cerris, Q. petraea or Fagus sylvatica (Roso sempervirentis-Quercetum pubescentis and other associations). In the more western and coastal parts, the dynamic transition takes place through the formation of juniper scrubs with Juniperus oxycedrus subsp. oxycedrus associated with various sclerophylls (Carici humilis-Juniperetum oxycedri Chiarucci, Foggi \& Selvi 1999, see Chiarucci et al. 1999) while in inner areas J. oxycedrus is associated with and Erica scoparia, E. arborea and xerophilous deciduous broad-leaved trees (Viciani et al. 2005). In Pinus pinaster forests (mostly deriving from old plantations) and afforested areas with Pinus nigra, the topsoil layers are subject to acidification, which attenuates the direct effects of the serpentine substrate (Selvi et al. 2017). In these situations, sub-steppic grasslands appear first (Festuco robustifoliae-Caricetum humilis Viciani, Foggi, Gabellini \& Rocchini 2002, see Chiarucci et al. 1996; Viciani et al. 2002), followed by Bromopsis erecta communities, then by dense Brachypodium rupestre communities, progressively colonized by Fabaceae and Rosaceae shrubs (Chiarucci 1994). There are also contacts with meso-xeric grasslands, generally perennial (Habitat 6210) but sometimes annual too (Habitat 6220*) and stable stages dominated by Calluna vulgaris, locally Erica cinerea, Buxus sempervirens or Juniperus communis (Habitat 4030, 5110, 5130) or with thorny gorse, mostly Genista desoleana (Habitat 4090) on screes and cliffs (Habitat 8210) (Lombini et al. 2001; Tomaselli et al. 2019a, 2021).

\section{[63xx] Centuries-old olive groves" with evergreen Quercus spp. and arborescent matorral}

Macrotype: 6 "Natural and semi-natural grassland formations" 63 "Sclerophillous grazed forests (dehesas)"
Type of proposal: New Habitat Proposed (E. Biondi, S. Casavecchia)

Reason for the proposal: the centuries-old olive groves of the Mediterranean territories represent a peculiar aspect of the rural landscape of southern Europe, the Near East and North Africa, well integrated into landscape contexts characterized by a good level of naturalness (Biondi et al. 2007). These are very complex ecosystems rich in biodiversity in which cultivated and spontaneous species harmoniously coexist; some of them are species of considerable conservation interest (Gangale and Uzunov 2003; Calabrese et al. 2012; Cohena et al. 2015). The habitat is also home to numerous species of wildlife that find refuge, food and reproduce there (Carpio et al. 2016). Secular olive groves are subject to serious pressures and threats from man and, if unprotected, they could quickly disappear (Trevisani 2004; Schicchi and Raimondo 2007). The causes are many: due to the relatively low production yield and the difficulties in crop care and harvesting, they are replaced with more modern systems, with more productive varieties and more suitable for agricultural mechanization. The old olive trees are also the object of reckless trade due to their high aesthetic value. To stem this phenomenon, the Puglia Region has promulgated a regional law (L.R.n. 14/2007) entitled "Protection and enhancement of the landscape of the monumental olive trees of Puglia".

Diagnostic sentence: a characteristic and historic landscape of the Mediterranean region with groves of centuries-old olive trees that extend through areas of Thermo and Meso-Mediterranean bioclimate and areas of the Sub-Mediterranean variant of the Temperate bioclimate. The habitat is characterized by evergreen oaks in the arborescent Matorral, and especially in southern-eastern Italy, by some fruit trees and shrubs as well as perennial grasslands with chamaephytes, hemicryptophytes and geophytes, used for the grazing of sheep and goats. This is a very important habitat for terrestrial fauna and birds as well.

Syntaxonomic reference: Oleo-Ceratonion siliquae Br.-Bl. ex Guinochet \& Drouineau 1944, Pistacio lentisci-Rhamnetalia alaterni Rivas-Martínez 1975, Quercetea ilicis Br.-Bl. in Br.-Bl., Roussine \& Nègre 1952.

Reference list of diagnostic species: Olea europaea, $O$. europaea var. sylvestris, Ceratonia siliqua, Quercus ilex, $Q$. virgiliana, Q. trojana, Prunus dulcis, Punica granatum.

Dynamic relationships and contacts: abandoned olive groves tend to rapidly transform into thick shrublands dominated by Pistacia lentiscus, Rhamnus alaternus, Phillyrea media, P. angustifolia, Olea europaea var. sylvestris and with Myrtus communis, Rosmarinus officinalis, Euphorbia dendroides, E. characias, Juniperus oxycedrus subsp. oxycedrus, and J. phoenicea subsp. turbinata (Biondi et al. 2014; Galié et al. 2015; Casavecchia et al. 2015). Over time, a sclerophyllous wood dominated by holm oak develops (Habitat 9340 "Quercus ilex and Quercus rotundifolia forests") or, where environmental conditions are favorable, mixed formations of evergreen and deciduous trees with Quercus virgiliana and Q. trojana on the Murg- 
ian plateau could occour (Habitat 9250 "Quercus trojana woods"). Catenal relationships: the habitat can be in spatial continuity with the Aleppo pine forests, with Turkey oak forests of Habitat 91M0 "Pannonian-Balkanic turkey oak- sessile oak forests" and with mixed forests dominated by the hop hornbeam.

\section{[65xx] Italian sub-montane and montane pastured meadows dominated by Cynosurus cristatus}

Macrotype: 6 "Natural and semi-natural grassland formations"; 65 "Mesophile grasslands" (European Commission 2013).

Type of proposal: New Habitat Proposed (G. Ciaschetti, E. Del Vico, D. Gigante)

Reason for the proposal: this habitat refers to semi-natural submontane and montane pastures and meadows usually grazed, and occasionally also mowed. Just like other Annex I Habitats (e.g., 6210) these communitites are depending on the persistence of a traditional land use (mowing, grazing), deeply related to the montane management systems: the increasing land abandonment and the consequent land use changes are causing their reduction and collapse (Blasi et al. 2009; Viciani et al. 2018). This semi-natural habitat host a remarkable rate of the montane biodiversity within the context of traditional agricultural landscapes (Gerdol and Piccoli 1980; Poldini and Oriolo 1994; Francalancia et al. 1995; Antrop 1997; Watkinson and Ormerod 2001; Ciaschetti and Pirone 2019). Compared to lowland hay meadows, these plant communities have a peculiar floristic richness, also due to the ingression of annuals colonizing the breakings in the grass turfs created as a result of the trampling action by grazing animals. The species composition tipically includes a certain rate of thorny, inappetite, or subnitrophilous species as a result of the grazing load. Rare species and various orchids can be present as well, especially in the central-southern Italian types. It is well known that traditional agricultural practices such as extensive grazing and mowing increase the vascular plant species richness and functional diversity (Hansson and Fogelfors 2000; Smith et al. 2000; Debussche et al. 2001; Pykälä 2004; Pykälä et al. 2005; Škornik et al. 2010; Vassilev et al. 2011; Blasi et al. 2012).

The plant communities belonging to the alliance $C y$ nosurion cristati have not been considered a habitat of European concern sensu 43/92/EEC Directive, as they are a broadly ranged and hosting prevalently species with a wide distribution. Indeed, there is no Annex I Habitat corresponding to montane and submontane hay meadows and/or pastured meadows. They have been sometimes referred to 6510 , however it is a stretch, since the latter refers to low altitude hay meadows. However, in Italy, in the Alpine and Apenninic context, these semi-natural pastures and pastured meadows host a particularly rich flora and a high number of endemic plants. Additionally, in the Mediterranean mountain ranges and in dry regions (such as Sardinia), they play a relic role hosting several boreal-temperate species confined to humid places (Bacchetta et al. 2012; Farris et al. 2013).

Diagnostic sentence: Mesophilous species-rich perennial grasslands dominated by hemicryptophytes, generally mowed once a year and/or extensively grazed by domestic livestock. These communities develop on flat areas or gentle slopes, including the karstic plains, on mature, nutrient-rich soils with a good water availability, mainly distributed in the Supratemperate and Mesotemperate (and, occasionally, Sub-Mesomediterranean) Bioclimatic Belts. These grasslands, characterized by a continuous and dense herb cover, are mostly dominated by Cynosurus cristatus. They are rich in biomass, hosting many other grass (often excellent as fodder, such as Lolium perenne) and leguminous species. They are typically characterized by the occurrence of plants related both to grazing and trampling as well, such as spiny and nitrophilous species.

Syntaxonomic reference: Cynosurion cristati Tüxen 1947, with the suballiaces: Cerastio arvensis-Cynosurenion cristati Blasi, Tilia, Rosati, Del Vico, Copiz, Ciaschetti \& Burrascano 2012, Trifolio resupinati-Cynosurenion cristati Blasi, Tilia, Rosati, Del Vico, Copiz, Ciaschetti \& Burrascano 2012, Danthonio decumbentis-Caricenion insularis Farris, Secchi, Rosati \& Filigheddu 2013; Trifolio repentis-Phleetalia pratensis Passarge 1969, Molinio-Arrhenatheretea Tüxen 1937; for Sicily: Plantaginion cupanii Brullo \& Grillo 1978, Cirsietalia vallis-demonis Brullo \& Grillo 1978, Molinio-Arrhenatheretea Tüxen 1937.

Reference list of diagnostic species: Cynosurus cristatus, Lolium perenne, L. pratense, L. apenninum, L. arundinaceus, Festuca rubra, Phleum pratense, P. nodosum, Anthoxanthum odoratum, Poa pratensis, P. trivialis, Trifolium repens, T. pratense subsp. pratense, Bellis perennis.

Dynamic relationships and contacts: The semi-natural meadows are, by definition, secondary cenoses whose maintenance is directly depending on the continuity of an extensive management, including yearly mowing, grazing and in some cases a sporadic light manure fertilization. The abandonment of these traditional practices leads to a rapid invasion by scrub stages, and to the re-colonization of the tree- dominated potential vegetation. The habitat is dynamically linked to shrubs of the order Prunetalia spinosae Tx. 1952 (especially Berberidion vulgaris $\mathrm{Br} . \mathrm{Bl}$ $1950)$ in the Supratemperate Belt, and to the order Pyro spinosae-Rubetalia ulmifolii Biondi, Blasi \& Casavecchia in Biondi, Allegrezza, Casavecchia, Galdenzi, Gasparri, Pesaresi, Vagge \& Blasi 2014 (Pruno spinosae-Rubion ulmifolii O. Bolòs 1954) in the Mesotemperate and Sub-Mesomediterranean bioclimates. The potential vegetation is generally represented by thermophilic beech woods [Aremonio agrimonioidis-Fagion sylvaticae (Horvat 1938) Borhidi in Török, Podani \& Borhidi 1989, Geranio versicoloris-Fagion sylvaticae Gentile 1970, Luzulo luzuloidis-Fagion sylvaticae Lohmeyer \& Tüxen in Tüxen 1954), edapho-mesophilic hornbeam woods [Erythronio dentis-canis-Carpinion betuli (Horvat 1958) Marinček in 
Wallnöfer, Mucina \& Grass 1993], subacidophilic Turkey oak woods [Crataego laevigatae-Quercion cerridis Arrigoni 1997, Physospermo-Quercion petreae A.O. Horvat 1976 [= Erythronio dentis-canis-Quercion petraeae Ubaldi (1988) 1990]. In spatial (catenal) contact with these communities, it is possible to find dry grasslands dominated by Bromopsis erecta (Bromion erecti Koch 1926, Phleo ambigui-Bromion erecti Biondi, Ballelli, Allegrezza \& Zuccarello ex Biondi \& Galdenzi 2012, belonging to Habitat 6210), hygrophilous grasslands belonging to the orders Trifolio-Hordeetalia Horvatić 1963 or Potentillo anserinae-Polygonetalia avicularis Tüxen 1947, acidophitic grasslands dominated by Nardus stricta of the Annex I Habitat 6230* (Biondi and Ballelli 1995; Catorci et al. 2007; Di Pietro et al. 2017).

\section{[91xx] Italian-balkan hop-hornbeam woods}

\author{
Macrotype: 9 "Forests"; 91 "Forests of temperate Eu- \\ rope"
}

Type of proposal: New Habitat Proposed (M. Allegrezza, L. Poldini, C. Lasen, M. Vidali)

Reason for the proposal: these are very extensive vegetation (more than 700,000 hectares in Italy) spread from Italy to the Balkan Peninsula. A high number of syntaxa and syntaxonomic review (e.g., Poldini 1988; Ubaldi 1995, 2003; Blasi et al. 2004, 2006; Poldini et al. 2017) have been published in Italy. These are rare examples of vegetation whose altitudinal extension on the Alps, Apennines and Balkania is so wide as to connect them with the Mediterranean horizon where they actively participate in meso-oro-Mediterranean formations (Quercetalia ilicis) to reach the subalpine types in contact with Erico-Pinetalia and Fagetalia up to mixed shrub formations with Ostrya and Rhododendron hirsutum. The cenoses of the karst area are also very rich in Illyrian-Balkan elements which here have their only Italian localities. They are habitats with a high natural value, which host rare, endemic and / or threatened species, including numerous orchids.

Diagnostic sentence: Italo-balkan meso-xerophile mixed woods clearly dominated by Ostrya carpinifolia. They are distributed from southern slopes of the Alps (with gravitation in the South-eastern Alps) to Apennines on preferably calcareous substrates, from the mesotemperate to the lower supratemperate thermotype, with ramifications in the mesomediterranean thermotype.

\section{Subtypes and variants:}

Subtype A. Ostrya carpinifolia woods in the south-eastern Alpine sector. Reference alliances Fraxino orni-Ostryion carpinifoliae (xerophilous woods rich in Erico-Pinetalia on more primitive soils) and Buglossoido purpurocaeruleae-Ostryion carpinifoliae (edaphomesoxerophilous and edaphomesophilous woods on more evolved soils). In the Fraxino orni-Ostryion carpinifoliae alliance, two geographical and ecological variants are distinguished: (i) subcontinental hop-hornbeam woods of the valleys of the Middle and South Tyrol (Saponario ocymoides-Querce- nion pubescentis); (ii) suboceanic hop-hornbeam woods of the south-eastern Alps (Seslerio caeruleae-Ostryenion carpinifoliae).

Subtype B. Ostrya carpinifolia woods of the karst-Balkan-Apennine sector of the Carpinion orientalis alliance, divided into five main geographical and ecological variants: (i) hop-hornbeam woods of the Ligurian-Piedmontese sector (Campanulo medii-Ostryenion carpinifoliae); (ii) zonal hop-hornbeam woods of the Trieste-Slovenian Karst (Seslerio autumnalis-Ostryenion carpinifoliae); (iii) extrazonal hop-hornbeam woods rich in Carpinus orientalis of the Trieste-Slovenian Karst (Ostryo-Carpinenion orientalis); (iv) mesophilic hop-hornbeam woods of the Apennines (Laburno anagyroidis-Ostryenion carpinifoliae); (v) thermophilic hop-hornbeam woods of the Apennines and pre-Apennine ridges (Lauro nobilis-Quercenion pubescentis).

Subtype C. Ostrya carpinifolia woods in the Tyrrhenian sector of the southern Apennines. Reference alliance Carpinion orientalis (sub-alliance Festuco exaltatae-Ostryenion carpinifoliae).

Syntaxonomic reference: Fraxino orni-Ostryion carpinifoliae Tomažič 1940 (Saponario ocymoides Quercenion pubescentis Poldini, Sburlino et Vidali 2017, Seslerio caeruleae-Ostryenion Ubaldi 2003), Buglossoido purpurocaeruleae-Ostryion carpinifoliae Poldini, Sburlino et Vidali 2017, Carpinion orientalis Horvat 1958 (Campanulo medii-Ostryenion carpinifoliae Terzi, Ciaschetti, Fortini, Rosati, Viciani et Di Pietro 2020, Ostryo-Carpinenion orientalis Poldini 1982, Seslerio autumnalis-Ostryenion carpinifoliae Blasi, Di Pietro et Filesi 2004, Laburno anagyroidis-Ostryenion carpinifoliae (Ubaldi 1995) Blasi, Di Pietro et Filesi 2004, Lauro nobilis-Quercenion pubescentis Ubaldi ex Ubaldi 1995, Festuco exaltatae-Ostryenion carpinifoliae Blasi, Filibeck et Rosati 2006), Quercetalia pubescenti-petraeae Klika 1933, Querco roboris-Fagetea sylvaticae Br.-Bl. \& Vlieger in Vlieger 1937.

Reference list of diagnostic species: Ostrya carpinifolia (dominant), Fraxinus ornus, Quercus pubescens s.l., Carpinus orientalis, Acer opalus subsp. obtusatum, A. monspessulanum, Emerus major s.l. (incl. subsp. emeroides e subsp. major), Cotinus coggygria, Aristolochia pallida (incl. A. lutea Desf.), Sesleria autumnalis, Sesleria caerulea.

Dynamic relationships and contacts: the forest cenoses of the new habitat typically represent the more mature term of the climatophilic series in the mesotemperate thermotype, but often also vegetations from edafoxerophilous to lithophilous, intrazonal, especially in the area of beech forests. Locally, on scree and sub-vertical walls, cenosis with a tall-shrubby structure are formed as durable formations.

In the Alpine sector, dynamic contacts are made mainly with the shrub communities of the Berberidion and Fraxino orni-Berberidenion, with the grasslands of the orders Scorzoneretalia villosae [(Habitat 62A0 "Eastern sub-mediterranean dry grasslands (Scorzoneretalia villosae)"], Seslerietalia caeruleae (Habitat 6170 "Alpine and subalpine calcareous grasslands") and Festucetalia valesi- 
acae [(Habitat $6210\left(^{*}\right)$ " Semi-natural dry grasslands and scrubland facies on calcareous substrates (Festuco-Brometalia) (*important orchid sites)"] in the most continental part (Alto Adige, Val Venosta). In the Apennines, hop-hornbeam woods are dynamically connected with the shrub communities of the Cytision sessilifolii alliance while the thermophilic Apennine and pre-Apennine ones with those of the Pruno-Rubion ulmifolii alliance. The grasslands in dynamic contact with these cenoses belong to Phleo ambigui-Bromion erecti alliance for the typically calcicolous aspects and Bromion erecti alliance on terrigenous substrates, both referable to Habitat $6210\left(^{*}\right)$.

\section{Discussion}

Although it is believed that it is more convenient and simple to propose implementations, such as adding subtypes or variants to existing habitats, we are convinced that in some cases, excessive forcing would be caused that lead to the distortion of the meaning of the habitat and its ambiguous interpretation. As an example, we can mention the attribution of Italian oak forests to Habitat $91 \mathrm{H} 0 *$ (Pannonian woods with Quercus pubescens) before the inclusion in Annex I of the Habitat 91 AA* following the entry of Romania and Bulgaria into the European Union. The description of "endemic" habitats for Italy, in addition to giving value to Italian phytocenotic and ecosystem biodiversity, also represents a "political" fact as, in our opinion, it gives greater importance to the biodiversity conservation policies.

Some of the proposed new habitats/new subtypes have a geographic jurisdiction that goes beyond the "borders" of central Italy, being in fact widespread throughout the national territory such as the Italo-Balkan hop-hornbeam woods or the habitat of freshwater large sedges and reeds beds. For these habitats, their diffusion at a national level is highlighted in the sheet, although the aspects relating to the conditions in which they occur in central Italy have been more in-depth discussed. As already mentioned, in the next future other articles about single habitats will be provided.

In general, it can be highlighted that the relative majority of the proposed habitats fall into macro-categories 3 (Fresh water habitats) and 6 (Natural and semi-natural grassland formations), together making up $60 \%$ of the new proposals.

This result is perfectly in line with the biodiversity conservation emergencies reported globally in relation to wet ecosystems which, due to global warming and the unsustainable exploitation of water resources, currently represent the ecosystems most threatened with disappearance (Titus 1988; Findlay and Bourdages 2000; Gibbs 2000; Nichols 2004; Coleman et al. 2008; Davidson and Nick 2014; $\mathrm{Hu}$ et al. 2017). On the other hand, grasslands represent an emergency at European level since, especially for secondary grasslands of anthropogenic origin, we are witnessing a significant rarefaction of this habitat due to the social transformations that involve the abandonment of traditional agro-pastoral practices on secondary grasslands. When abandoned, they are destined to disappear due to the natural processes of recovery by the woody vegetation. On the contrary, if they are subjected to intensive management, they undergo a deep transformation in terms of species composition to the advantage of more productive and profitable herbaceous crops but, consequently, of lesser or no naturalistic interest. Substituting traditional sheeps and goats flocks with more productive and less expensive cows and horses herds produce negative impact on these habitats too.

Alongside these general considerations, with regard to individual habitats, some comments can be added.

[31xx] Freshwater large sedge and reed beds: three subtypes can be identified concerning this habitat. The first subtype is related to the vegetation dominated by large sedges, that are developed on the edge of lakes, humid depressions and peat bogs, on more or less submerged soils that remain soaked in water for the entire year. Many sedge species are involved, some of them very rare in Italy as Carex buxbaumii, C. disticha, C. vulpina and C. acuta (Pirone 1987; Pedrotti 2015, 2016; Ciaschetti et al. 2021; Venanzoni et al. 2021). In these cases, the habitat can be considered as priority. Other species not listed in the sheet are Carex paniculata, C. riparia, C. rostrata, C. acutiformis, C. otrubae, C. microcarpa, C. randalpina, C. appropinquata, C. hispida, C. diandra, C. lasiocarpa, and Cyperus longus.

The second subtype is related to the vegetation dominated by graminoid helophytes developed in stations permanently submerged by stagnant or slowly flowing waters, often subject to seasonal fluctuations. Other species, besides those listed in the sheet, are Schoenoplectus lacustris, Schoenoplectiella mucronata, Typha domingensis, T. latifolia, T. laxmannii, T. shuttleworthii.

The third subtype is about sedges, graminoids and tallherb communities of banks that grow on-stabilized organic substrates (floating mass of vegetation built by the communities themselves) that are partly or completely floating.

[32xx] Shrubby willow formations of river banks and fens: for this new habitat, two subtypes are currently known. The first subtype deals with shrubby willow grooving on flat, hilly and Mediterranean-mountain areas: pioneer shrubby willows communities (Salix purpurea subsp. purpurea, subsp. lambertiana and subsp. eburnea, S. triandra, S. brutia, S. amplexicaulis, S. pedicellata, $S$. ionica) that colonize the gravelly-pebbly river deposits, subject to periodic flooding, especially in autumn and winter. They represent the first stage of colonization of the river banks by wood species. The second subtype consists of shrublands of swampy areas characterized by gray willow (Salicion cinereae): shrub formations dominated by Salix cinerea that colonize the swampy areas of the alluvial plains and the edges of lakes and ponds that remain swamped even during the summer period. 
[40xx] Apennine hilly and montane garrigues: the floristic composition of this habitat is very rich; indeed, alongside the species cited as the most significant at a diagnostic level, other important rare species occur, such as Alyssoides utriculata, Lotus hirsutus, Artemisia alba, sometimes in very restricted areas such as the case of Ephedra major and Cytisus decumbens. Furthermore, endemic and subendemic species such as Santolina etrusca, Onosma pseudoarenaria subsp. lucana, Achillea rupestris subsp. calcarea, Calendula suffruticosa subsp. fulgida, Plocama calabrica, Genista pulchella subsp. aquilana, Centaurea ceratophylla subsp. ceratophylla, and Centaurea scannensis are frequent.

[6130] Communities of herbaceous and dwarf shrub-suffrutescent plants of Italian ultramafic substrates: for this new subtype of Habitat 6130, five variants can be identified. The first one refers to low suffrutescent-herbaceous communities of Liguria, Toscana, Emilia-Romagna and Piemonte, referable to the associations Armerio denticulatae-Alyssetum bertolonii and Biscutello prinzerae-Alyssetum bertolonii. The second variant occurs on active extraction sites and old abandoned mining sites and quarries of Val d'Aosta, Piemonte, Liguria, Lombardia, Friuli Venezia Giulia, Toscana and Sardegna. It deals with aspects located in mining sites (secondary sites), mostly abandoned, with more or less mobile artificial deposits with medium-thin sediments, colonized to various degrees by metallicolous, herbaceous or suffrutescent species (or ecotypes), distinguished mainly based on the chemical characteristics of the deposits. The third variant refers to formations of central-eastern Liguria, Toscana and Emilia-Romagna, dominated by hemisphaerical cushions of Euphorbia spinosa; these are referable to the associations Euphorbio spinosae-Genistetum desoleanae (Liguria), Armerio-Alyssetum bertolonii subass. euphorbietosum spinosae (western Toscana) and Euphorbio spinosae-Cistetum monspeliensis (Elba Island). The fourth variant is formed by Serpentine steppes represented by sub-steppes of central-eastern Toscana (Val Tiberina), Liguria and Piemonte (Val di Susa, Valli di Lanzo, etc.), dominated by perennial grasses referable, at least in part, to the association Festuco robustifoliae-Caricetum humilis and by substeppes dominated by perennial grasses partially referable to the association Cerastio suffruticosi-Seslerietum pichianae. Finally, the fifth variant refers to Alpine heavy metal communities dealing with high-altitude pioneer grasslands of Val d'Aosta (M. Avic) referable to the association Caricetum fimbriatae.

As regards as the floristic composition of these formation, a rich contingent of specie occurs alongside those already cited: Bromopsis erecta, Cardamine plumieri, Carex fimbriata, Carex humilis, Centaurea aplolepa (subsp. aplolepa, carueliana, lunensis), Danthonia alpina, Festuca cinerea, F. inops, Leucanthemum pachyphyllum, Noccaea coerulescens, Odontharrhena argentea, O. bertolonii, Plantago subulata, Sabulina verna, Scorzonera austriaca, Sesamoides interrupta, Stachys recta, Stipa bromoides, S. etrusca, S. tirsa, Thymus striatus subsp. acicularis, in addition to numerous endemic taxa with a restricted range, Cerastium utriense, Santolina ligustica, Viola bertolonii, Echium anchusoides and other metallicolous ecotypes, such as, Alpagrostis alpina, Festuca luedii, F. stricta, Agrostis tenuis, Avenella flexuosa, Silene vulgaris, S. paradoxa.

Finally, it is important to underline that the communities strictly found on ultramafic cliffs and screes deposits (chasmophytic, comophytic and glareicolous) should be referred to other types of Habitats (8220 [62.21 and/ or 62.28] and 8130 respectively). Further problems arise from the comparison with the Habitats 4090, 6110 and 8230 with which they share some diagnostic species and some ecological and site characteristics.

[63xx] "Centuries-old olive groves" with evergreen Quercus subsp. and arborescent matorral: one of the most important diagnostic species is Olea europaea L. var. sylvestris (Mill.) Leht (Olea europaea subsp. oleaster (Mill.) Rouy ex Hegi) spontaneous taxon of the Mediterranean shrubland, mainly occurring in the coastal areas of southern Italy and Sardinia (Pignatti 2018); the wild variety is no longer considered to have any taxonomic value (Bartolucci et al. 2018) but, despite this, considering its phytosociological significance (a characteristic entity of the alliance Oleo-Ceratonion) and its importance in the recolonization processes of the maquis, it was considered appropriate to put it among the diagnostic species. Concerning the species of flora that participate in the composition of the habitat, it is worth mentioning: Pinus halepensis, Quercus calliprinos, Ficus carica, Sorbus domestica, Rhamnus alaternus, Pistacia lentiscus, Myrtus communis, Rosmarinus officinalis, Phillyrea media, P. angustifolia, Euphorbia dendroides, E. characias, E. wulfenii, Juniperus oxycedrus subsp. oxycedrus, J. phoenicea subsp. turbinata, Anagyris foetida, Ampelodesmos mauritanicus, Rubus ulmifolius, Spartium junceum, Calicotome infesta and endemic and subendemics orchids of genus Ophrys (O. celiensis, O. apulica, O. tarentina, O. garganica, O. candica, O. tardans, etc.).

[65xx] Italian submontane and montane pastured meadows dominated by Cynosurus cristatus: the habitat holds a huge geographical variability, reverberating in the floristic composition that allows the detection of five subtypes. The first one is related to the Alps, with coenoses more similar to those of Central Europe and charachterized by a strong presence of Eurasian, boreal and orophile species. A second subtype groups the C-N-Apennine communities, that can be interpreted as transition aspects between the Alpic and southern coenoses, with characteristic ingressions of species coming from more or less xerophilic Bromopsis erecta dominated prairies. The third subtype is spread in C-S-Apennine in a transitional oceanic climate, so with more mediterranean influence both by a biogeographical and climatic point of view, leading to the presence of thermophilous and annual species. Sardinian communities represent a fourth subtype linked to upper mesotemperate to lower supratemperate humid bioclimates, characterized by the richness of sardinian endemic species, some of which are worthy of particular 
attention. The last subtype concerns with the coenoses of Sicily, more thermophilous, with a strong presence of species endemic to Sicily or Aspromonte.

[91xx] Italian-Balkan hop-hornbeam woods: the diagnostic sentence reported in the sheet refers to the main distribution of the habitat in Italy whose maximum expression with the clearly dominant Ostrya carpinifolia is achieved from the south-eastern Alps to the Apennine ridge. In this first phase, the localized distribution of the habitat in Sardinia (Bacchetta et al. 2009) was not considered, as well as the ravine formations of Sicily (Bartolo et al. 1990) and southern Italy (Brullo et al. 2001) where O. carpinifolia has relictual character. However, syntaxonomic updates are in progress, some of which have already been partially published in Poldini et al. (2017).

\section{Conclusion}

In conclusion, some reflections are needed.

First of all, it should be emphasized again that the list of habitats presented here and briefly discussed can be integrated with other new habitats or subtypes. Furthermore, it is necessary to better define the distribution range of these habitats through detailed analyses and necessary insights through the involvement of the entire scientific community that has been dealing with the conservation of biodiversity and problems related to the Natura 2000 network for decades.

Although the list presented here is certainly not exhaustive and the new types of habitats must certainly be better defined, we want to underline once again the need to include all the biodiversity of Italian natural and semi-natural biotopes in the application of the Directive, also considering their very important role as biological corridors that are necessary for the conservation not only of the floristic-vegetational component but also of microand macro-fauna.

\section{Bibliography}

Adorni M, Tomaselli M (2002) Ricerche sulla vegetazione di un'Area Protetta con substrati ofiolitici: la Riserva Naturale Monte Prinzera (Appennino parmense). In: Saccani A (Ed.) Le ofioliti isole sulla terra ferma, Per una rete di Aree Protette. Atti del Convegno Nazionale 22-23 giugno 2001. Graphital, Parma, 195-210.

Allegrezza M (2003) Vegetazione e paesaggio vegetale della dorsale del Monte S. Vicino (Appennino centrale). Fitosociologia 40 (Suppl. 1): 3-118.

Allegrezza M, Ballelli S, Mentoni M, Olivieri M, Ottaviani C, Pesaresi S, Tesei G (2013) Biodiversity in the Sibillini Mountain range (Sibillini National Park, central Apennines): the example of Piè Vettore. Plant Sociology 50: 57-89. https://doi.org/10.7338/pls2013501/06

Allegrezza M, Biondi E, Brilli-Cattarini AJB, Gubellini L (1993) Emergenze floristiche e vegetazionali della Val Marecchia. Biogeographia 17: 25-49. https://doi.org/10.21426/B617110407
Allegrezza M, Biondi E, Formica E, Ballelli S (1997) La vegetazione dei settori rupestri calcarei dell'Italia centrale. Fitosociologia 32: 91-120.

Angiolini C, Bacchetta G, Brullo S, Casti M, Giusso del Galdo G, Guarino R (2005)The vegetation of mining dumps in SW Sardinia. Feddes Repertorium 115: 243-276. https://doi.org/10.1002/fedr.200411072

Angiolini C, Landi M, Boddi M, Frignani F (2005) La vegetazione dell'alveo fluviale del sito d'importanza regionale torrente Trasubbie (Grosseto, Toscana meridionale). Atti della Società Toscana di Scienze Naturali, Memorie, Serie B 112: 127-151.

Angiolini C, Scoppola A, De Dominicis V (1998) The stream beds in southern Tuscany (central Italy): influence of some environmental features on chamaephytic vegetation. Acta Botanica Neerlandica 47(3): 313-324.

Angiolini C, Viciani D, Bonari G, Lastrucci L (2017) Habitat conservation prioritization: A floristic approach applied to a Mediterranean wetland network. Plant Biosystems 151(4): 598-612.https://doi.org/ 10.1080/11263504.2016.1187678

Angold PG, Sadler JP, Hill MO, Pullin A, Rushton S, Austin K, Small E, Wood B, Wadsworth R, Sanderson R, Thompson K (2006) Biodiversity in urban habitat patches. Science of The Total Environment 360(1-3): 196-204. https://doi.org/10.1016/j.scitotenv.2005.08.035

Antoni AM (1965) Il paesaggio vegetale delle colline argillose dell'alta e media Val d'Orcia (Siena). Webbia 20: 427-454. https://doi.org/10.1 p80/00837792.1965.10669821

Antrop M (1997) The concept of traditional landscapes as a base for landscape evaluation and planning: the example of Flanders region. Landscape and Urban Planning 38: 105-117. https://doi. org/10.1016/S0169-2046(97)00027-3

Arrigoni PV, Papini P (2003) La vegetazione del sistema fluviale Lima Serchio (Toscana meridionale). Parlatorea 6: 95-129.

Arrigoni PV, Ricceri C, Mazzanti A (1983) La vegetazione serpentinicola del Monte Ferrato di Prato in Toscana. Centro di Scienze Naturali, Prato, 27 pp.

Bacchetta G, Bagella S, Biondi E, Farris E, Filigheddu R, Mossa L (2009) Vegetazione forestale e serie di vegetazione della Sardegna (con rappresentazione cartografica alla scala 1.350.000). Fitosociologia 46 (Suppl. 1): 3-82.

Bacchetta G, Farris E, Pontecorvo C (2012) A new method to set conservation priorities in biodiversity hotspots. Plant Biosystems 146(3): 638-648.

Bacchetta G, Mossa L (2004) Studio fitosociologico delle cenosi a Carex microcarpa Bertol. ex Moris della Sardegna meridionale. Fitosociologia 41 (Suppl. 1): 171-178.

Bartolo G, Brullo S, Minissale P, Spampinato G (1990) Contributo alla conoscenza dei boschi a Quercus ilex della Sicilia. Acta Botanica Malacitana 15: 203-215. https://doi.org/10.24310/abm.v15i.9303

Biondi E (2000) Syntaxonomy of the Mediterranean chamaephytic and nanophanerophytic vegetation in italy. Colloques Phytosociologiques 27: 123- 145.

Biondi E, Allegrezza M, Casavecchia S, Pesaresi S, Vagge I (2006) Lineamenti vegetazionali e paesaggio dell'Appennino centrale e settentrionale. Biogeografia 27: 35-129. https://doi.org/10.21426/B6110014

Biondi E, Allegrezza M, Guitian J, Taffetani F (1988) La vegetazione dei calanchi di Sasso Simone e Simoncello (Appennino tosco-marchigiano). Braun-Blanquetia 2: 105-115.

Biondi E, Baldoni M (1994) La vegetazione del fiume Marecchia (Italia Centrale). Biogeografia 17 (1993): 51-87. https://doi.org/10.21426 B617110369 
Biondi E, Ballelli S (1995) Le Praterie del Monte Coscerno e Monte di Civitella (Appennino Umbro Marchigiano -Italia centrale). Fitosociologia 30: 91-121.

Biondi E, Ballelli S, Allegrezza M, Manzi A (1990) La vegetazione dei calanchi di Gessopalena (Abruzzo meridionale). Documents Phytosociologiques 12: 257-263.

Biondi E, Ballelli S, Allegrezza M, Taffetani F, Francalancia C (1994) La vegetazione delle "fiumare" del versante ionico lucano-calabro. Fitosociologia 27: 51-66.

Biondi E, Ballelli S, Taffetani F (1992) La vegetazione di alcuni territori calanchivi in Basilicata (Italia meridionale). Documents Phytosociologiques 14: 489-498.

Biondi E, Biscotti N, Casavecchia S, Marrese M (2007) "Oliveti secolari": habitat nuovo proposto per l'inserimento nell'Allegato I della Direttiva (92/43CEE). Fitosociologia 44(2) Suppl. 1: 213-218.

Biondi E, Biscotti N, Pesaresi S, Casavecchia S (2014) The Daphne sericea Vahl vegetation in the Gargano promontory (Southern Italy). Plant Sociology 51 (2): 57-68.

Biondi E, Blasi C, Burrascano S, Casavecchia S, Copiz R, Del Vico E, Galdenzi D, Gigante D, Lasen C, Spampinato G, Venanzoni R, Zivkovic L (2009) Manuale Italiano di interpretazione degli habitat della Direttiva 92/43/CEE. Società Botanica Italiana. Ministero dell'Ambiente e della Tutela del Territorio e del Mare, D.P.N. http:/ vnr.unipg.it/habitat

Biondi E, Blasi C (2015) Prodromo della Vegetazione Italiana. MATTM, SBI. Available online at http://www.prodromo-vegetazione-italia org [accessed on 2021, Oct 30].

Biondi E, Burrascano S, Casavecchia S, Copiz R, Del Vico E, Galdenzi D, Gigante D, Lasen C, Spampinato G, Venanzoni R, Zivkovic L, Blasi C (2012) Diagnosis and syntaxonomic interpretation of Annex I Habitats (Dir. 92/43/EEC) in Italy at the alliance level. Plant Sociology 49(1): 5-37.

Biondi E, Casavecchia S, Paradisi L, Pesaresi S (2007) La vegetazione del medio e basso corso del Metauro. In: Poggiani L, Dionisi V, Gubellini L (Eds) Boschi di fiume. Ambiente, flora e fauna dei boschi ripariali del Metauro. Quaderni dell'Ambiente 20: 25-41.

Biondi E, Pesaresi S (2004) The badland vegetation of the northern-central Appennines (Italy). Fitosociologia 41(1) Suppl.1: 155-170.

Biondi E, Vagge I, Baldoni M, Taffetani F (1997) La vegetazione del Parco Fluviale Regionale del Taro (Emilia-Romagna). Fitosociologia 34: 69-110.

Biondi E, Vagge I, Baldoni M, Taffetani F (1999) La vegetazione del Parco Fluviale Regionale dello Stirone (Emilia-Romagna). Fitosociologia 36(1): 67-93.

Biondi E, Vagge I, Fogu MC, Mossa L (1995) La vegetazione del letto ciottoloso dei fiumi della Sardegna meridionale (Italia). Colloques Phytosociologiques 24: 813-825.

Blasi C, Burrascano S, Del Vico E, Di Pietro R, Iocchi M, Rosati L (2009) Cynosurion cristati grasslands in the central Apennines (Tyrrhenian sector): A phytosociological survey in the Lepini and Prenestini mountains. Plant Biosystems 143 (Suppl. 1): 69-77. https://doi org/10.1080/11263500903498192

Blasi C, Di Pietro R, Filesi L (2004) Syntaxonomical revision of Quercetalia pubescenti-petraeae in the Italian peninsula. Fitosociologia 41(1): 87-164.

Blasi C, Filibeck G, Rosati L (2006) Classification of Southern Italy Ostrya carpinifolia woods. Fitosociologia 43(1): 3-23.
Blasi C, Tilia A, Rosati L, Del Vico E, Copiz R, Ciaschetti G, Burrascano S (2012) Geographical and ecological differentiation in Italian mesophilous pastures referred to the alliance Cynosurion cristati Tx. 1947. Phytocoenologia 41(4): 217-229. https://doi.org/10.1127/0340 269X/2011/0041-0504

Bonini I, Angiolini C, Chiarucci A, De Dominicis V (1999) Syntaxonomic analysis of garigues on calcareous soil of central Tuscany (Italy). Fitosociologia 36(2): 103-112.

Branconi S, De Dominicis V, Boscagli A, Boldi L (1980) La vegetazione dei terreni argillosi pliocenici della Toscana meridionale. I. Vegetazione pioniera ad Artemisia cretacea. Atti della Società Toscana di Scienze Naturali, Memorie, Serie B 86 (1979): 163-183.

Brullo S (1985a) Contributo alla conoscenza della vegetazione nitrofila della Sicilia. Colloques Phytosociologiques 12: 23-148.

Brullo S (1985b) Sur la syntaxonomie des pelouses thérophytiques des territoires steppiques de l'Europe sud-occidentale. Documents Phytosociologiques 9: 1-24.

Brullo S, De Marco G, Signorello P (1990) Studio fitosociologico delle praterie a Lygeum spartum dell'Italia meridionale. Bollettino Accademia Gioenia Scienze Naturali Catania 23(336): 561-579.

Brullo S, Grillo M, Scalia C (1980) Su una nuova associazione dei Pegano-Salsoletea osservata presso Porto Empedocle (Agrigento). Giornale Botanico Italiano 114: 43-52. https://doi. brg/10.1080/11263508009426433

Brullo S, Guarino R, Ronsisvalle G (1998) La vegetazione del litorale di Manfria, presso gela (Sicilia), area soggetta a vincolo archeologico. Archivio Geobotanico 4(1): 91-107.

Brullo S, Guglielmo A, Pavone P (1985) La classe Pegano-Salsoletea in Sicilia. Bollettino Accademia Gioenia Scienze Naturali Catania 18: 247-254.

Brullo S, Scelsi F, Spampanato G (2000) Salix ionica (Saliceceae) a new species from S Italy. Bocconea 13: 419-423.

Brullo S, Scelsi F, Spampinato G (2001) La vegetazione dell'Aspromonte. Studio fitosociologico. Laruffa Editore, Villa San Giovanni (Reggio Calabria), $368 \mathrm{pp}$.

Brullo S, Siracusa G (1998) Indagine fitosociologica su di un'area umida del versante sud-occidentale dell'Etna di notevole interesse naturalistico. Archivio Geobotanico 4(1): 71-90.

Brullo S, Spampinato G (1990) La vegetazione dei corsi d'acqua della Sicilia. Bollettino Accademia Gioenia Scienze Naturali Catania 23 (336): 119-252.

Brullo S, Spampinato G (1993) A new species of Salix (Salicaceae) form Calabria (S Italy). Candollea 48: 291-295.

Brullo S, Spampinato G (1997) Indagine fitosociologica sulle ripisilve della Calabria (Italia meridionale). Lazaroa 18: 105-151.

Buffa G, Miserere L, Montacchini F (1998) Aspetti della vegetazione di altitudine del Parco Naturale del Mont Avic. Revue Valdôtaine d'Histoire Naturelle 52: 35-48.

Calabrese G, Tartaglini N, Ladisa G (2012) Study on biodiversity in century-old olive groves. CIHEAM - Mediterranean Agronomic Institute of Bari, 97pp.

Camporeale C, Perucca E, Ridolfi L, Gurnell AM (2013) Modeling the interactions between river morphodynamics and riparian vegetation. Reviews of Geophysics 51: 379-414. https://doi.org/10.1002 rog.20014

Caniglia G, Mondin F, Carpene' B (1992) Aspetti floristico-vegetazionali di un lobo di meandro del Parco del Sile (S. Michele Vecchio - Venezia). Lavori della Società Veneziana di Scienze Naturali 17: 151-173. 
Cardoso P (2012) Habitats Directive species lists: urgent need of revision. Insect Conservation and Diversity 5(2): 169-174. https://doi. org/10.1111/j.1752-4598.2011.00140.x

Carnelli A, Mariotti MG, Peri F, Zocchi G (1994) Indagini preliminari sull'ecologia di alcune piante vascolari in siti minerari della Lombardia. Giornale Botanico Italiano 128: 307. https://doi. org/10.1080/11263509409437137

J, Oteros J, Tortosa FS, Guerrero-Casado J (2016) Land use and biodiversity patterns of the herpetofauna: The role of olive groves. Acta Oecologica 70: 103-111. https://doi.org/10.1016/j.actao.2015.12.007

Casavecchia S, Biscotti N, Pesaresi S, Biondi E (2015) The Paliurus spina-christi dominated vegetation in Europe. Biologia 70: 879-892. https://doi.org/10.1515/biolog-2015-0100

Catorci A, Gatti R, Balzelli S (2007) Studio fitosociologico della vegetazione delle praterie montane dell'Appennino maceratese (Italia centrale). Braun-Blanquetia 42: 101-143.

Ceschin S, Salerno G (2008) La vegetazione del basso corso del Fiume Tevere e dei suoi affluenti (Lazio, Italia). Fitosociologia 45: 39-74.

Chapin FS III, Zavaleta ES, Eviner VT, Naylor RL, Vitousek PM, Reynolds HL, Hooper DU, Lavorel S, Sala OE, Hobbie SE, Mack MC, Díaz S (2000) Consequences of changing biodiversity. Nature 405: 234242. https://doi.org/10.1038/35012241

Chiarucci A (1994) Successional pathway of Mediterranean ultramafic vegetation in central Italy. Acta Botanica Croatica 53: 83-94.

Chiarucci A (2004) Vegetation Ecology and Conservation on Tuscan Ultramafic Soils. The Botanical Review 69(3): 252-268. https://doi.org 10.1663/0006-8101(2003)069[0252:VEACOT]2.0.CO;2

Chiarucci A, Bonini I, Gonnelli V, De Dominicis V (1996) The Stipa tirsa communities of the Upper Tiber valley, Italy and their conservation. Colloques Phytosociologiques 24 (1995): 305-309.

Chiarucci A, Bonini I, Maccherini S, De Dominicis V (1995a) Influence of colonizing Spartium junceum scrub on Bromus erectus grassland in a biancana badland of the Orcia Valley, Tuscany. Archivio Geobotanico 1(2): 127-134.

Chiarucci A, De Dominicis V, Ristori J, Calzolari C (1995b) Biancana badland vegetation in relation to soil and morphology in Orcia Valley, central Italy. Phytocoenologia 25: 69-87. https://doi.org/10.1127 phyto/25/1995/69

Chiarucci A, Foggi B, Selvi F (1995) Garigue plant communities of ultramafic outcrops of Tuscany (Central Italy). Webbia 49(2): 179-192. https://doi.org/10.1080/00837792.1995.10670581

Chiarucci A, Foggi B, Selvi F (1999) The Juniperus oxycedrus ssp. oxycedrus scrub communities of Tuscan serpentine soils. Atti della Società Toscana di Scienze Naturali, Memorie, Serie B 105 (1998): 51-57.

Chiarucci A, Maccherini S, Bonini I, De Dominicis V (1998b) Effects of nutrient addition on species diversity and ground cover of "serpentine" vegetation. Plant Biosystems 132(2): 143-150. https://doi.org/1 $0.1080 / 11263504.1998 .10654199$

Chiarucci A, Mariotti M (1999) Rimboschimenti a conifere e consorzi erbaceo-arbustivi della Val di Vara: osservazioni floristiche ed ecologiche. Memorie della Accademia lunigianese di scienze lettere ed arti Giovanni Capellini 67/69: 343-351.

Chiarucci A, Riccucci M, Celesti C, De Dominicis V (1998c) Vegetation-environment relationships in the ultramafic area of Monte Ferrato, Italy. Israel Journal of Plant Sciences 46: 213-221. https://doi.or g/10.1080/07929978.1998.10676730

Chiarucci A, Robinson BH, Bonini I, Petit D, Brooks RR, De Dominicis V (1998a) Vegetation of Tuscan ultramafic soils in relation to edaph- ic and physical factors. Folia Geobotanica 33(2): 113-131. https:// loi.org/10.1007/BF02913340

Ciaschetti G, Pirone G (2019) Lathyro asphodeloidis-Klaseetum lycopifoliae, a new plant association in the alliance Cynosurion cristati Tüxen 1947 in Central Apennines. Italian Botanist 7: 35-50. https://doi. org/10.3897/italianbotanist.7.33361

Ciaschetti G, Pirone G, Giancola C, Frattaroli A.R. et Stanisci A, 2016. Prodrome of the Italian vegetation: A new alliance for the high mountain chamaephytic communities of central and southern Apennines. Plant Biosystems 150(4): 829-833. https://doi.org/10.10 80/11263504.2015.1076084

Ciaschetti G, Pirone G, Venanzoni R (2021) Sedge vegetation of the "Major Highlands of Abruzzo" (Central Italy): updated knowledge after new discoveries. Plant Biosystems 155(3): 647-662. https://doi.org/1 $0.1080 / 11263504.2020 .1801876$

Cohen M, Bilodeau C, Alexandre F., Godron M, Andrieu J, Grésillon E, Garlatti F, Morganti A (2015) What is the plant biodiversity in a cultural landscape? A comparative, multi-scale and interdisciplinary study in olive groves and vineyards (Mediterranean France). Agriculture, Ecosystems and Environment 212: 175-186. https://doi. brg/10.1016/j.agee.2015.06.023

Coleman JM, Huh OK, Braud Jr D (2008) Wetland loss in world deltas. Journal of Coastal Research 24: 1-14. https://doi.org/10.2112/05 0607.1

Corbetta F, Pirone G (1989) La vegetazione del fiume Tirino (Abruzzo). Archivio Botanico e Biogeografico Italiano 65 (3-4): 121-153.

Corbetta F, Ubaldi D, Zanotti AL (1991) La vegetazione a Lygeum spartum nei calanchi della valle del Basento (Basilicata). Archivio Botanico e Biogeografico Italiano 67(3-4): 51-74.

Cutini M, Cancellieri L, Ceschin S, Lucchese F, Caneva G (2007) Analisi cenologica e sintassonomica delle garighe a Salvia officinalis $\mathrm{L}$. lucane nel quadro dei salvieti peninsulari (Basilicata, Appennino meridionale). Webbia 62(2): 225-244. https://doi.org/10.1080/0083 792.2007 .10670825

D'Amico ME, Bonifacio E, Zanini E (2013) Relationships between serpentine soils and vegetation in a xeric inner Alpine environment. Plant and Soil 376: 111-128. https://doi.org/10.1007/s11104-013 1971-y

D'Amico ME, Previtelli F (2012) Edaphic influence of ophiolitic substrates on the vegetation in the Western Italian Alps. Plant and Soil 351: 73-95. http://dx.doi.org/10.1007/s11104-011-0932-6

Davidson NC (2014) How much wetland has the world lost? Long-term and recent trends in global wetland area. Marine and Freshwater Research 65(10): 934-941. https://doi.org/10.1071/MF14173

Debusschee M, Debusschee G, Lepart J (2001) Changes in the vegetation of Quercus pubescens woodland after cessation of coppicing and grazing. Journal of Vegetation Science 12: 81-92. https://doi. org/10.1111/j.1654-1103.2001.tb02619.8

Di Pietro R, Germani D, Fortini P (2017) A phytosociological investigation on the mixed hemycryptophitic and therophitic grasslands of the Cornicolani mountains (Lazio Region - central Italy). Plant Sociology 54(1): 107-128.

Dudgeon D, Arthington AH, Gessner MO, Kawabata Z, Knowler DJ, Lévêque C, Naiman RJ, Prieur-Richard A, Soto D, Stiassny MLJ, Sullivan CA (2006) Freshwater biodiversity: importance, threats, status and conservation challenges. Biological Research 81: 163-182. https://doi.org/10.1017/S1464793105006950 
EEA (2021) EUNIS terrestrial habitat classification 2021 including crosswalks. Available at https://www.eea.europa.eu/data-and-maps/ data/eunis-habitat-classification-1/eunis-terrestrial-habitat-classification-review-2021/eunis-terrestrial-habitat-classification-2021) at_download/file

Ernst W (1974) Schwermetallvegetation der Erde. Geobotanica Selecta, Band V. Gustav Fischer Verlag, Stuttgart.

Ernst W (1976) Violetea calaminariae R.Tx. 1961. J. Cramer, Lehre.

European Commission (2013) Interpretation manual of European Union habitats - EUR28. European Commission, Brussels, 144 pp.

European Union (1992) Council Directive 92/43/EEC of 21 May 1992 on the conservation of natural habitats and of wild fauna and flora. Official Journal of the European Union 206 (1992): 7-50.

Evans D (2006) The habitats of the European Union habitats directive. Biology and Environment: Proceedings of the Royal Irish Academy. Royal Irish Academy. https://doi.org/10.3318/BIOE.2006.106.3.167

Farris E, Secchi Z, Rosati L, Filigheddu R (2013) Are all pastures eligible for conservation? A phytosociological survey of the Sardinian-Corsican Province as a basic tool for the Habitats Directive. Plant Biosystems 147(4): 931-946. https://doi.org/10.1080/11263504.2013.778911

Fascetti S, Lapenna MR (2007) Studio conoscitivo di base per il progetto di rinaturalizzazione del SIC-ZPS "Valle Basento-Grassano Scalo-Grottole" (Basilicata- Italia meridionale). Fitosociologia 44(2) Suppl. 1: 23-29.

Ferrari C (1971) La vegetazione dei Calanchi nelle Argille Scagliose del Monte Paderno. Notiziario della Società Italiana di Fitosociologia 6: 31-51.

Ferrari C, Gerdol G (1987) Numerical syntaxonomy of badland vegetation in the Appennines Italy. Phytocoenologia 15: 21-37. https://doi. org/10.1127/phyto/15/1987/21

Ferrari C, Grandi G (1974) La vegetazione dei calanchi nelle argille plioceniche della Valle del Santerno (Emilia Romagna). Archivio Botanico e Biogeografico Italiano 50(3-4): 3-15.

Ferrari C, Speranza M (1975) La vegetazione dei calanchi dell'Emilia-Romagna (con note di sistematica per la vegetazione dei suoli alomorfi interni). Notiziario della Società Italiana di Fitosociologia 10: 69-86.

Findlay CS, Bourdages J (2000) Response time of wetland biodiversity to road construction on adjacent lands. Conservation Biology 14(1): 86-94. https://doi.org/10.1046/j.1523-1739.2000.99086.x

Foggi B, Cartei L, Pignotti L, Signorini MA, Viciani D, Dell'Olmo L, Menicagli E (2006) Il paesaggio vegetale dell'Isola d'Elba (Arcipelago Toscano). Studio fitosociologico e cartografico. Fitosociologia 43(Suppl. 1): 3-95.

Foggi B, Selvi F, Viciani D, Bettini D, Gabellini A (2000) La vegetazione forestale del bacino del Fiume Cecina (Toscana centro-occidentale). Parlatorea 4: 39-73.

Foggi B, Venturi E (2009) Gli habitat meritevoli di conservazione della Provincia di Prato. In: Fancelli E (Ed.) Biodiversità in Provincia di Prato. 4. Habitat. Editrice le Balze, Roma.

Fois M, Bacchetta G, Caria MC, Cogoni D, Farris E, Fenu G, Manca M, Pinna MS, Pisanu S, Rivieccio G, Bagella S (2021) Proposals for improvement of Annex I of Directive 92/43/EEC: Sardinia. Plant Sociology 58(2): 65-76. https://doi.org/10.3897/pls2021582/06

Francalancia C, Galli P, Paradisi L (1995) Variazioni nella composizione floristica dei prati a Cynosurus cristatus L. delle alte Valli di Tazza e Fematre (Appennino marchigiano), in rapporto alle pratiche colturali. Fitosociologia 29: 89-93.
Galié M, Gasparri R, Perta RM, Biondi E, Biscotti N, Pesaresi S, Casavecchia S (2015) Post-fire regeneration of Calicotome villosa (Poiret) Link. and vegetation analysis. Plant Sociology 52(2): 101-120. https://doi.org/10.7338/pls2015522/06

Gangale C, Uzunov D (2003) Floristic composition of traditional olive grove in Ionian coast of South Italy. Bocconea 16(2): 783-792.

Gentile S, Di Benedetto G (1961) Su alcune praterie a Lygeum spartum L. e su alcuni aspetti di vegetazione di terreni argillosi della Sicilia orientale e Calabria meridionale. Delpinoa 3: 67-151.

Gentile S, Sartori F, 1975 (1974-75) La vegetazione dei calanchi nei terreni eo-miocenici delle valli Staffora e Curone. Stadi e tendenze dinamiche. Atti dell'Istituto Botanico e Laboratorio Crittogamico dell' Università di Pavia 10(6): 59-115.

Gerdol R, Piccoli F (1980) Inquadramento fitosociologico e valutazione ecologica delle formazioni prative montane del Monte Baldo. Archivio Botanico e Biogeografico Italiano 56(3-4): 101-133.

Gianguzzi L, Cusimano D, Cuttonaro P, Gianguzzi G, Romano S (2014a) Distribution, ecology and conservation survey on the Celtis tournefortii subsp. aetnensis (Celtidaceae: Cannabaceae) populations in Sicily. Webbia 69(2): 325-334. https://doi.org/10.1080/00837792.20 14.971586

Gianguzzi L, Cusimano D, Ilardi V, Romano S (2013) Distribution, ecology, vegetation and conservation survey on the relictual population of Carex panormitana Guss. (Cyperaceae) in Sicily (Italy). Webbia 68 (2): 159-175. https://doi.org/10.1080/00837792.2013.853364

Gianguzzi L, Cusimano D, Romano S (2014b) Phytosociological characterization of the Celtis tournefortii subsp. aetnensis microwoods in Sicily. Plant sociology 51(2): 17-28.

Gianguzzi L, Cuttonaro P, Cusimano D, Romano S (2016b) Contribution to the phytosociological characterization of the forest vegetation of the Sicani Mountains (inland of the nort-western Sicily). Plant sociology 53(1): 5-42.

Gianguzzi L, D'Amico A (2006) Su alcuni aspetti di vegetazione forestale localizzati nella Valle del Fiume Oreto e l'opportunità di una loro tutela finalizzata anche al recupero del paesaggio naturale. In: Ferro V. (ed) Riqualificazione ambientale dei corsi d'acqua. Quaderni di Idronomia Montana 25: 419-434.

Gianguzzi L, D'Amico A, Caldarella O (2008) Habitat e specie d'interesse prioritario nel SIC Rocche di Entella (Sicilia centro-occidentale). Atti del $43^{\circ}$ Congresso Società Italiana di Scienza della Vegetazione (Ancona 25-27 Giugno 2007). Fitosociologia 44(2) Suppl. 1: 201-205.

Gianguzzi L, Papini F, Cusimano D (2016a) Phytosociological survey vegetation map of Sicily (Mediterranean region. Journal of Maps 12(5): 845-851. https://doi.org/10.1080/17445647.2015.1094969

Gibbs James P (2000) Wetland loss and biodiversity conservation. Conservation biology 14(1): 314-17. https://doi.org/10.1046/j.1523 1739.2000.98608.x

Gigante D, Angiolini C, Landucci F, Maneli F, Nisi B, Vaselli O, Venanzoni R, Lastrucci L (2014) New occurrence of reed bed decline in southern Europe: Do permanent flooding and chemical parameters play a role in common reed bed decline in Central Italy? Comptes Rendus Biologies 337: 487-498. https://doi.org/10.1016/j. crvi.2014.05.005

Gigante D, Venanzoni R, Zuccarello V (2011) Reed die-back in southern Europe? A case study from Central Italy. Comptes Rendus Biologies 334: 327-336. https://doi.org/10.1016/j.crvi.2011.02.004

Guarino R, Pasta S, Bazan G, Crisafulli A, Caldarella O, Giusso del Galdo GP, Silvestre Gristina A, Ilardi V, La Mantia A, Marcenò C, Minis- 
sale P, Sciandrello S, Scuderi L, Spampinato G, Troia A, Gianguzzi L (2021) Relevant habitats neglected by the Directive 92/43 EEC: the contribution of Vegetation Science for their reappraisal in Sicily. Plant Sociology 58(2): 49-63. https://doi.org/10.3897/pls2021582/05

Halada L, Evans D, Romão C, Petersen J-E (2011) Which habitats of European importance depend on agricultural practices?. Biodiversity and Conservation 20: 2365-2378. https://doi.org/10.1007/s10531 011-9989-z

Hansson M, Fogelfors H (2000) Management of a semi-natural grassland: results from a 15-year-old experiment in southern Sweden. Journal of Vegetation Science 11: 31-38. https://doi.org/10.2307/3236772

Hochkirch A, Schmitt T, Beninde J, Hiery M, Kinitz T, Kirschey J, Matenaar D, Rohde K, Stoefen A, Wagner N, Zink A, Lötters S, Veith M, Proelss A (2013). Europe needs a new vision for a Natura 2020 network. Conservation Letters 6: 462-467. https://doi.org/10.1111 conl.12006

Hooke JM (2006) Human impacts on fluvial systems in the Mediterranean region. Geomorphology 79 (3-4): 311-335. https://doi. org/10.1016/j.geomorph.2006.06.036

Hu S, Niu Z, Chen Y, Li L, Zhang H (2017) Global wetlands: Potential distribution, wetland loss, and status. Science of the Total Environment 586: 319-327. https://doi.org/10.1016/j.scitotenv.2017.02.001

Kalníková V, Chytrý K, Biţa-Nicolae C, Bracco F, Font X, Iakushenko D, Kącki Z, Kudrnovsky H, Landucci F, Lustyk P, Milanović Đ, Šibík J, Šilc U, Uziębło AK, Villani M, Chytrý M (2021) Vegetation of the European mountain river gravel bars: A formalized classification. Applied Vegetation Science 24: e12542. https://doi.org/10.1111 avsc. 12542

Kumschick S, Gaertner M, Vilà M, Essl F, Jeschke JM, Pyšek P, Ricciardi A, Bacher S, Blackburn TM, Dick JTA, Evans T, Hulme PE, Kühn I, Mrugała A, Pergl J, Rabitsch W, Richardson DM, Sendek A, Winter M (2015) Ecological impacts of alien species: quantification, scope, caveats, and recommendations. Bioscience 65: 55-63. https://doi. org/10.1093/biosci/biu193

Landi M, Angiolini C, De Dominicis V (2002) Analisi fitosociologica dei fiumi della Toscana meridionale: il tratto medio-basso del Merse (Italia centrale). Studia Botanica 21: 37-88.

Landucci F, Gigante D, Venanzoni R, Chytrý M (2013) Wetland vegetation of the class Phragmito-Magno-Caricetea in central Italy. Phytocoenologia 43 (1-2): 67-100. https://doi.org/10.1127/0340 269X/2013/0043-0545

Landucci F, Šumberová K, Tichý L, Hennekens S, Aunina L, Biță-Nicolae C, Borsukevych L, Bobrov A, Čarni A, De Bie E, Golub V, Hrivnák R, Iemelianova S, Jandt U, Jansen F, Kącki Z, Lájer K, Papastergiadou E, Šilc U, Sinkevičienė Z, Stančić Z, Stepanovič J, Teteryuk B, Tzonev R, Venanzoni R, Zelnik I, Chytrý M (2020) Classification of the European marsh vegetation (Phragmito-Magnocaricetea) to the association level. Applied Vegetation Science 23: 297-316. https://doi. org/10.1111/avsc.12484

Lastrucci L, Bonari G, Angiolini C, Casini F, Giallonardo T, Gigante D, Landi M, Landucci F, Venanzoni R, Viciani D (2014) Vegetation of Lakes Chiusi and Montepulciano (Siena, central Italy): updated knowledge and new discoveries. Plant Sociology 51(2): 29-55.

Lastrucci L, Cerri M, Coppi A, Dell'olmo L, Ferranti F, Ferri V, Filipponi F, Foggi B, Galardini R, Reale L, Venanzoni R, Viciani D, Gigante D (2019) Spatial landscape patterns and trends of declining reed-beds in peninsular Italy. Plant Biosystems 153(3): 427-435. https://doi.org 10.1080/11263504.2018.1498401
Lastrucci L, Cerri M, Coppi A, Ferranti F, Ferri V, Foggi B, Lazzaro L, Reale L, Venanzoni R, Viciani D, Gigante D (2017) Understanding common reed die-back: a phytocoenotic approach to explore the decline of palustrine ecosystems. Plant Sociology 54(2) Suppl. 1: 15-28.

Lastrucci L, Gigante D, Vaselli O, Nisi B, Viciani D, Reale L, Coppi A, Fazzi V, Bonari G, Angiolini C (2016) Sediment chemistry and flooding exposure: a fatal cocktail for Phragmites australis in the Mediterranean basin? Annales de Limnologie - International Journal of Limnology 52: 365-377. https://doi.org/10.1051/limn/2016023

Lastrucci L, Landucci F, Gonnelli V, Barocco R, Foggi B, Venanzoni R (2012) The vegetation of the upper and middle River Tiber (Central Italy). Plant Sociology 49 (2): 29-48.

Lazzaro L, Bolpagni R, Buffa G, Gentili R, Lonati M, Stinca A, et al. (2020) Impact of invasive alien plants on native plant communities and Natura 2000 habitats: State of the art, gap analysis and perspectives in Italy. Journal of Environmental Management 274: 111140. https://doi.org/10.1016/j.jenvman.2020.111140

Lockwood M (2006) Global protected area framework. In: Lockwood M, Graeme V, Kothari A (Eds) Managing protected areas: a global guide. Cromwell Press, Trowbridge, UK, 73-100.

Lombini A, Ferrari C, Carpenè B (2001) The ecology of the ofiolitic scree vegetation: a survey on the Northern Appennine outcrops (Italy). Bocconea 13: 561-571.

Loppi S, De Dominicis V (1990) La vegetation des terrains argilleux pliocenes en Toscane. V. Enquete sur des prairies naturelles de la Valdera (Volterra) en relation au sol. Documents Phytosociologiques 12: 321-342.

Maccherini S, Chiarucci A, De Dominicis V (1998) Relazioni tra la vegetazione e la morfologia nei calanchi di Radicofani (Toscana meriodionale). Atti del Museo di Storia Naturale della Maremma 17: 91-108.

Maes D, Collins S, Munguira ML, Šašić M, Settele J, van Swaay C, Verovnik R, Warren M, Wiemers M, Wynhoff I (2013) Not the right time to amend the annexes of the European Habitats Directive. Conservation Letters 6.6: 468-469. https://doi.org/10.1111/conl.12030

Malmqvist B, Rundle S (2002) Threats to the running water ecosystems of the world. Environmental Conservation 29: 134-153. https://doi. org/10.1017/S0376892902000097

Marchiori S, Sburlino G (1996) Present vegetation of the Venetian Plain. Allionia 34: 117-132.

Mariotti MG (1994) Osservazioni sulle formazioni a Buxus sempervirens e a Genista salzmannii della Liguria orientale. Memorie della Accademia lunigianese di Scienze Lettere ed Arti Giovanni Capellini 59: 77-125.

Mariotti MG (2008) Atlante degli Habitat Natura 2000 in Liguria. Regione Liguria, Genova.

Mariotti MG, Carnelli A (1995) Ricerche sulla variabilità in popolazioni metallotolleranti e non di Silene vulgaris (Moench) Garcke. Giornale Botanico Italiano 129(2): 149.

Marsili S, Barberis G (2012) Note floristiche piemontesi dal Parco di Capanne di Marcarolo (Alessandria). Informatore Botanico Italiano 44: 121-124.

McNeely JA, Schroth G (2006) Agroforestry and biodiversity conservation-traditional practices, present dynamics, and lessons for the future. Biodiversity and Conservation 15(2): 549-554. https://doi. org/10.1007/s10531-005-2087-3

Mereu L, Lastrucci L, Viciani D (2012) Contributo alla conoscenza della vegetazione del fiume Pesa (Toscana, Italia centrale). Studia Botanica 29 (2010): 105-143. 
Merloni N, Piccoli F (2001) La vegetazione del complesso Punte Alberete e Valle Mandriole (Parco Regionale del Delta del Po - Italia). Braun-Blanquetia 29: 1-17.

Moreno-Saiz JC, Albertos B, Ruiz-Molero E, Mateo RG (2021) The European Union can afford greater ambition in the conservation of its threatened plants. Biological Conservation 261: 109231. https://doi. org/10.1016/j.biocon.2021.109231

Mucina L, Bultmann H, Dierßen K, Theurillat Jp, Raus T,Carni A, Sumberova K, Willner W, Dengler J, Gavilan Gr, et al. (2016) Vegetation of Europe: Hierarchical floristic classification system of vascular plant, bryophyte, lichen, and algal communities. Applied Vegetation Science 19 (Suppl. 1): 3-264. https://doi.org/10.1111/avsc.12257

Musarella CM, Mendoza-Fernández AJ, Mota JF, Alessandrini A, Bacchetta G, Brullo S, et al. (2018) Checklist of the gypsophilous vascular flora in Italy. PhytoKeys 103: 61-82. https://doi.org/10.3897 phytokeys.103.25690

Nicholls RJ (2004) Coastal flooding and wetland loss in the 21st century: changes under the SRES climate and socio-economic scenarios. Global Environmental Change 14(1): 69-86. https://doi. org/10.1016/j.gloenvcha.2003.10.007

Nowak B (1987) Untersuchungen zur Vegetation Ostliguriens (Italien). Dissertationes Botanicae 111. J. Cramer, Berlin - Stuttgart. VII + 260 pp.

Oprea A, Sârbu I (2009) Other natural habitats types (under Habitat Directive 92/43/EEC) in Romania. Analele Universităţii Oradea 16: 95-98.

Pasta S (2001) Recenti acquisizioni floristico-vegetazionali sull'area delle Macalube di Aragona. Naturalista Siciliano 25: 155-196.

Pedrotti F (1990) Note sulla flora e vegetazione del lago di Madrano (Trentino). Informatore Botanico Italiano 22(3): 182-193.

Pedrotti F (1995) Nota sulla vegetazione degli ambienti umidi della Bassa Valsugana (Trentino). Documents Phytosociologiques 15: 417-449.

Pedrotti F (2015) A new plant association of Caricion gracilis alliance of the Central Apennines (Italy). Contribuţii Botanice 50: 137-152.

Pedrotti F (2016) The Caricetum distichae Association in Italy. In: Vegetation Structure and Function at Multiple Spatial, Temporal and Conceptual Scales. Geobotany Studies, Springer, Berlin-New York, 357-362. https://doi.org/10.1007/978-3-319-21452-8_14

Pedrotti F, Gafta D (1996) Ecologia delle foreste ripariali e paludose dell'Italia. L'uomo e l'ambiente 23: 1-163.

Pignatti Wikus E, Pignatti S (1977) Die Vegetation auf Serpentin-Standorten in den Nördlichen Apenninen. In: Studia phytologica: (Dissertationes ex Parte Utiles ad Studia Comparativa Vegetationis Mecsekensis): in Honorem Jubilantis A. O. Horvát, MTA Pécsi Bizottsága, Pécs, 113-124.

Pirone G (1981a) La vegetazione dei calanchi nelle argille plioceniche del subappennino abruzzese. Archivio Botanico e Biogeografico Italiano 57: 133-153.

Pirone G (1981b) Osservazioni preliminari sulla vegetazione legnosa ripariale del fiume Pescara (Abruzzo). Notiziario della Società Italiana di Fitosociologia 17: 45-54.

Pirone G (1987) I magnocariceti degli Altipiani Maggiori d'Abruzzo. Informatore Botanico Italiano 19(2): 131-135.

Pirone G (1991) Flora e Vegetazione del fiume Saline (Abruzzo). Micologia e Vegetazione Mediterranea 6(1): 45-76.

Pirone G (1995) Vegetazione dei calanchi di Atessa (Abruzzo) e problematiche sintassonomiche della vegetazione calanchiva appenninica in fitoclimi temperato-mediterranei di transizione. Fitosociologia, 30: 221-232.
Pirone G (2000) La vegetazione ripariale nei versanti nord-orientali del Gran Sasso e dei Monti della Laga (Abruzzo, Italia). Fitosociologia 37 (2): 65-86.

Pirone G, Ciaschetti G, Di Martino L, Di Cecco V, Frattaroli AR (2014) Contributo alla conoscenza delle garighe collinari e submontane dell'Appennino centrale. Micologia e Vegetazione Mediterranea 29(1): 75-92.

Pirone G, Ciaschetti G, Frattaroli AR, Corbetta F (2003). La vegetazione della Riserva Naturale Regionale "Lago di Serranella" (Abruzzo - Italia). Fitosociologia 40 (2): 55-71.

Pirone G, Frattaroli F, Ciaschetti G (2018) Contribution to knowledge of Apennine colline-submontane garigues on terrigenous rock types. Plant Sociology 55(1): 53-64.

Pirone G, Tammaro F (1997) The hilly calciophilous garigues in Abruzzo (Central Apennines, Italy). Fitosociologia 32: 73-90.

Poldini L (1988) Übersicht des Verbandes Ostryo-Carpinion orientalis (Quercetalia pubescentis) in SO-Europa. Phytocoenologia 16(1): 125-143. https://doi.org/10.1127/phyto/16/1988/125

Poldini L, Oriolo G (1994) La vegetazione dei prati da sfalcio e dei pascoli intensivi (Arrhenatheretalia e Poo-Trisetetalia) in Friuli (NE Italia). Studia Geobotanica 14 (Suppl. 1): 3-48.

Poldini L, Sburlino G, Vidali M (2017) New syntaxonomic contribution to the Vegetation Prodrome of Italy, Plant Biosystems 151(6): 11111119. https://doi.org/10.1080/11263504.2017.1303003

Presti G, Di Filippo C, Blasi C (2005) La vegetazione igrofila del Monumento Naturale Pantane e Lagusiello (Lazio centrale). Informatore Botanico Italiano 36: 401-408.

Prosser F, Sarzo A (2004) L'area umida relitta di Roncafort: un biotopo di eccezionale interesse botanico (Trentino, Italia settentrionale). Annali del Museo Civico di Rovereto, Sezione Archeologia Storia Scienze Naturali 19: 233-280.

Pykälä J (2004) Cattle grazing increases plant species richness of most species trait groups in mesic semi-natural grasslands. Plant Ecology 175: 217-226. https://doi.org/10.1007/s11258-005-0015-y

Pykälä J, Luoto M, Heikkinen RK, Kontula T (2005) Plant species richness and persistence of rare plants in abandoned semi-natural grasslands in northern Europe. Basic and Applied Ecology 6: 25-33. https://doi.org/10.1016/j.baae.2004.10.002

Pỳsek P, Jaršík V, Hulme PE, Pergl J, Hejda M, Schaffner U, Vilà M (2012) A global assessment of invasive plant impacts on resident species, communities and ecosystems: the interaction of impact measures, invading species' traits and environment. Global Change Biology 18 (5): 1725-1737. https://doi.org/10.1111/j.1365-2486.2011.02636.x

Raimondo FM, Bazan G, Gianguzzi L, Ilardi V, Schicchi R, Surano N (2000) Carta del paesaggio e della biodiversità vegetale della Provincia di Palermo. Quaderni di Botanica Ambientale e Applicata 9 (1998): 3-160.

Saccani A (1998) Il monte Prinzera (Emilia-Romagna) In: Corbetta F, Abbate G, Frattaroli AR, Pirone G (Eds) SOS verde, vegetazioni e specie da conservare. 17. Le rupi e i brecciai. Edagricole, Bologna, 388-390.

Saccani A (ed), 2001. Le ofioliti isole sulla terra ferma, Per una rete di Aree Protette. Atti del Convegno Nazionale 22-23 giugno 2001: 195-210.

Saccani A (2002) Le ofioliti: isole sulla terraferma. Per una rete di Aree Protette. Atti del Convegno Nazionale 22-23 giugno 2001. Graphital, Parma, 468 pp. 
Saccani A, Salvati M (2015) Gioielli della flora delle alte valli Taro e Ceno (Appennino Emiliano, Parma). Conoscere e salvaguardare le specie endemiche, rare e protette. Stamperia scrl, Parma, 800 pp.

Sartori F, Bracco F (1995) Flora e vegetazione del Po. Accademia delle Scienze di Torino. Quaderni 1: 139-191.

Sartori F, Bracco F (1997) Present vegetation of the Po plain in Lombardy. Allionia 34 (1996): 113-135.

Schicchi R, Raimondo FM (1999) Contributo alla conoscenza degli alberi monumentali delle Madonie (Sicilia centro-settentrionale). Naturalista Siciliano 23(1-2): 229-314.

Scoppola A, Angiolini C (1997) Considerazioni ecologiche e sintassonomiche su alcune garighe dell'entroterra fra Siena e Viterbo (Italia centrale). Fitosociologia 32: 121-134.

Selvi F (2007) Diversity, geographic variation and conservation of the serpentine flora of Tuscany (Italy). Biodiversity and Conservation 16: 1423-1439. https://doi.org/10.1007/s10531-006-6931-x

Selvi F, Carrari E, Colzi I, Coppi A, Gonnelli C (2017) Responses of serpentine plants to pine invasion: Vegetation diversity and nickel accumulation in species with contrasting adaptive strategies. Science of the Total Environment 595: 72-80. https://doi.org/10.1016/j.scitotenv.2017.03.249

Škornik S, Vidrih M, Kaligarič M (2010) The effect of grazing pressure on species richness, composition and productivity in North Adriatic Karst pastures. Plant Biosystems 144: 355-364. https://doi. org/10.1080/11263501003750250

Smith LS, Shiel LS, Millward D, Corkhill P (2000) The interactive effects of management on the productivity and plant community structure of an upland meadow: an 8-year field trial. Journal of Applied Ecology 37: 1029-1043. https://doi.org/10.1046/j.1365-2664.2000.00566.x

Strumia S (2004) Contributo alla conoscenza delle cenosi ripariali del fiume Volturno (Campania). Delpinoa n.s. 46: 63-70.

Stubbington R, Sarremejane R, Laini A, Cid N, Csabai Z, England J, et al. (2021). Disentangling responses to natural stressor and human impact gradients in river ecosystems across Europe. Journal of Applied Ecology 00: 1-12.https://doi.org/10.1111/1365-2664.14072

Taffetani F (2000) Serie di vegetazione del complesso geomorfologico del Monte dell'Ascensione (Italia centrale). Fitosociologia 37 (1): 93-151.

Tardella FM, Di Agostino VM (2020) Wetland vegetation of the "Altipiani di Colfiorito" (central Apennines, Italy). Plant Sociology 57(2): 113-132. https://doi.org/10.3897/pls2020572/04

Tasinazzo S (2009) La vegetazione dei prati dei "Pra' dei Gai" nella Pianura Veneta orientale (NE Italia). Fitosociologia 46(2): 35-47.

Titus JG (1988) Sea level rise and wetland loss: an overview. In: Titus JG ( Ed.) Greenhouse Effect, Sea Level Rise, and Coastal Wetlands. US Environmental Protection Agency, Washington DC, 186pp.

Tomaselli M, Bolpagni R, Gualmini M, Petraglia A, Longhi D (2006) Studio fitosociologico, cartografia della vegetazione ed analisi dello stato trofico delle acque delle "Paludi del Busatello" (Italia settentrionale). Bollettino del Museo Civico di Storia Naturale di Verona. Botanica Zoologia 30: 3-37.

Tomaselli M, Carbognani M, Foggi B, Adorni M, Petraglia A, Whittingham Forte T, Segadelli S, Rossi G, Gennai G (2021) Scree vegetation in the northern Apennines (N-Italy). Phytocoenologia 51: 39-94. https://doi.org/10.1127/phyto/2021/0391

Tomaselli M, Carbognani M, Foggi B, Petraglia A, Rossi G, Lombardi L, Gennai M (2019a) The primary grasslands of the northern Apennine summits (N-Italy): a phytosociological and ecological survey. Tuexenia 39: 181-213.

Tomaselli M, Foggi B, Carbognani M, Gennai M, Petraglia A (2019b) The rock-face vegetation in the northern Apennines and neighbouring mountain areas, from the coast line to the highest summits. Phytocoenologia 49: 7-70. https://doi.org/10.1127/phyto/2018/0117

Tomei PE, Monacci F, Sani A, Trimarchi S (2009) La vegetazione della provincia di Pisa. Ambito delle Colline Pisane tra la Valle d'Elsa e la Valle del Tora. Edizioni ETS, Pisa, 52 pp.

Torma A, Bozsó M, Gallé R (2018) Secondary habitats are important in biodiversity conservation: a case study on orthopterans along ditch banks. Animal Biodiversity and Conservation 41.1: 97-108. https:// doi.org/10.32800/abc.2018.41.0097

Torri D, Santi E, Marignani M, Rossi M, Borselli L, Maccherini S (2013) The recurring cycles of biancana badlands: Erosion, vegetation and human impact. Catena, 106: 22-30. https://doi.org/10.1016/j.catena.2012.07.001

Trivisani A (2004) Gli olivi secolari di Castrum Boletum e Rotunda Maris. Progr. Leader Plus, Regione Basilicata.

Ubaldi D (1995) Tipificazione di syntaxa forestali appenninici e siciliani. Studi sul territorio. Annali di Botanica (Roma) 51(1): 113-126.

Ubaldi D (2003) La vegetazione boschiva d'Italia. Manuale di fitosociologia forestale. CLUEB, Bologna.

Vagge I (1997) Le garighe a Genista desoleana Valsecchi ed Euphorbia spinosa L. subsp. ligustica (Fiori) Pign. della Liguria orientale (Italia NW). Fitosociologia 32: 239-243.

Van Oorschot M, Kleinhans MG, Geerling GW, Egger G, Leuven RSEW, Middelkoop H (2017) Modeling invasive alien plant species in river systems: Interaction with native ecosystem engineers and effects on hydro-morphodynamic processes. Water Resources Research 53: 6945-6969. https://doi.org/10.1002/2017WR020854

Van Swaay C, Collins S, Dušej G, Maes D, Munguira ML, Rakosy L, Ryrholm N, Šašić M, Settele J, Thomas JA, Verovnik R, Verstrael T, Warren M, Wiemers M, Wynhoff I (2012) Dos and Don'ts for butterflies of the Habitats Directive of the European Union. Nature Conservation 1: 73-153. https://doi.org/10.3897/natureconservation.1.2786

Vassilev K, Pedashenko H,Nikolov SC, Apostolova I, Dengler J (2011) Effect of land abandonment on the vegetation of upland semi-natural grasslands in the Western Balkan Mts., Bulgaria. Plant Biosystems 145: 654-665. https://doi.org/10.1080/11263504.2011.601337

Venanzoni R, Apruzzese A, Gigante D, Vale F (2003) Contributo alla conoscenza della vegetazione acquatica ed idrofitica dei laghi di Monticchio. Informatore Botanico Italiano 35 (1): 69-80.

Venanzoni R, Gigante D (2000) Contributo alla conoscenza della vegetazione degli ambienti umidi dell'Umbria (Italia). Fitosociologia 37 (2): $13-63$.

Venanzoni R, Praleskouskaya S, Ciaschetti G (2021) Contribution to the Syntaxonomy of Rare Tall Sedge Community in Central Apennine (Umbria-Italy): I. Caricetum buxbaumii. Flora Mediterranea 31 (Special Issue): 95-104. https://doi.org/10.7320/FlMedit31SI.095

Venanzoni R, Properzi A, Bricchi E, Landucci F, Gigante D (2018) The Magnocaricetalia Pignatti 1953 (Phragmito-Magnocaricetea Klika in Klika et Novák 1941) Plant Communities of Italy. Geobotany Studies, Springer, Berlin-New York, pp 135-173. https://doi. org/10.1007/978-3-319-67967-9_8

Viciani D, Dell'Olmo L, Gabellini A, Gigante D, Lastrucci L (2018) Landscape dynamics of Mediterranean montane grasslands over 60 
years and implications for habitats conservation: a case study in the northern Apennines (Italy). Landscape Research 43(7): 952-964. https://doi.org/10.1080/01426397.2017.1400526

Viciani D, Foggi B, Gabellini A, Rocchini D (2002) Contributo alla conoscenza delle praterie su substrati ultramafici dell'Alta Valtiberina (Toscana orientale, Italia). Fitosociologia 39(1): 127-134.

Viciani D, Gabellini A, Gonnelli V, De Dominicis V (2005) La vegetazione della Riserva Naturale Monti Rognosi (Arezzo, Toscana) ed i suoi aspetti di interesse botanico-conservazionistico. Atti della Società Toscana di Scienze Naturali, Memorie, Serie B 111 (2004): 27-42. Vörösmarty CJ, McIntyre PB, Gessner MO, Dudgeon D. Prusevich A, Green P, Glidden S, Bunn SE, Sullivan CA, Reidy Lierman C, Davies PM (2010) Global threats to human water security and river biodiversity. Nature 467: 555-561. https://doi.org/10.1038/nature09440
Watkinson AR, Ormerod SJ (2001) Grasslands, grazing and biodiversity: editors' introduction. Journal of Applied Ecology 38: 233-237. https://doi.org/10.1046/j.1365-2664.2001.00621.x

Young J, Watt A, Nowicki P, Alard D, Clitherow J, Henle K, Johnson R, Laczko E, McCracken D, Matouch S, Niemela J, Richards C (2005) Towards sustainable land use: identifying and managing the conflicts between human activities and biodiversity conservation in Europe. Biodiversity and Conservation 14: 1641-1661. https://doi. org/10.1007/s10531-004-0536- 2

Zangheri P (1942) Flora e vegetazione dei calanchi argillosi pliocenici della Romagna e della zona di argille in cui sono distribuiti. Lega, Faenza, 281 pp.

Zanotti Censoni AL, Corbetta F, Aita L (1980) Carta della vegetazione della Tavoletta "Trivigno" (Basilicata). C.N.R., Roma. 